\title{
Energy Storage Technical and Economic Analysis Program: Annual Report
}

November, 1985

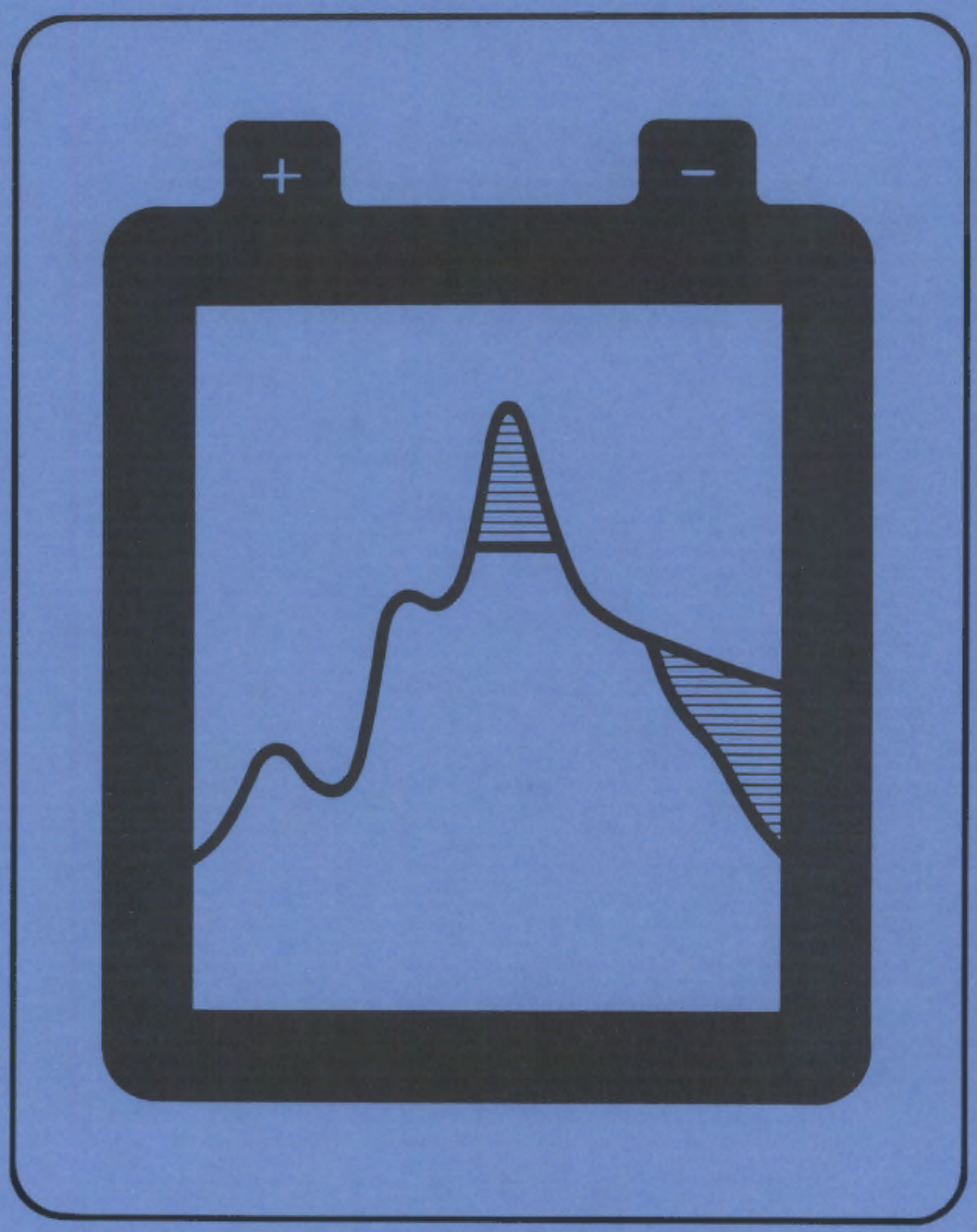

Prepared for the U.S. Department of Energy under Contract DE-AC06-76RLO 1830

Pacific Northwest Laboratory Operated for the U.S. Department of Energy by Battelle Memorial Institute 


\title{
DISCLAIMER
}

This report was prepared as an account of work sponsored by an agency of the United States Government. Neither the United States Government nor any agency thereof, nor any of their employees, makes any warranty, express or implied, or assumes any legal liability or responsibility for the accuracy, completeness, or usefulness of any information, apparatus, product, or process disclosed, or represents that its use would not infringe privately owned rights. Reference herein to any specific commercial product, process, or service by trade name, trademark, manufacturer, or otherwise, does not necessarily constitute or imply its endorsement, recommendation, or favoring by the United States Government or any agency thereof. The views and opinions of authors expressed herein do not necessarily state or reflect those of the United States Government or any agency thereof.

\author{
PACIFIC NORTHWEST LABORATORY \\ operated by \\ BATTELLE \\ for the \\ UNITED STATES DEPARTMENT OF ENERGY \\ under Contract DE-AC06-76RLO 1830
}

\begin{tabular}{|c|c|}
\hline \multicolumn{2}{|c|}{$\begin{array}{l}\text { Printed in the United States of Ameri } \\
\text { Available from } \\
\text { National Technical information Servi } \\
\text { United States Department of Commer } \\
5285 \text { Port Royal Road } \\
\text { Springfield, Virginia } 22161\end{array}$} \\
\hline \multicolumn{2}{|c|}{$\begin{array}{l}\text { NTIS Price Codes } \\
\text { Microfiche A01 }\end{array}$} \\
\hline \multicolumn{2}{|c|}{ Printed Copy } \\
\hline Pages & $\begin{array}{l}\text { Price } \\
\text { Codes }\end{array}$ \\
\hline $001-025$ & $\mathrm{~A} 02$ \\
\hline $026-050$ & $\mathrm{~A} 03$ \\
\hline $051-075$ & $\mathrm{~A} 04$ \\
\hline $076-100$ & $A 05$ \\
\hline $107-125$ & $A 06$ \\
\hline $126-150$ & $\mathrm{~A} 07$ \\
\hline 151.175 & $\mathrm{~A} 08$ \\
\hline $176-200$ & $A 09$ \\
\hline $201-225$ & $A 010$ \\
\hline $226-250$ & A011 \\
\hline $251-275$ & $A 012$ \\
\hline $276-300$ & $\mathrm{~A} 013$ \\
\hline
\end{tabular}




\section{1}

PNL -5678

UC $-94 \mathrm{C}$

ENERGY STORAGE TECHNICAL AND ECONOMIC

ANALYSIS PROGRAM: ANNUAL REPORT

November 1985

Prepared for

the U.S. Department of Energy

under Contract DE-AC06-76RL0 183h

Pacific Northwest Laboratory

Richland, Washington 99352 
$+$

,

. 
The Technical and Economic Analysis (TEA) Program, under the direction of the Pacific Northwest Laboratory (PNL), supports the Energy Storage Program that is coordinated by the U.S. Department of Energy's (DOE) office of Energy Storage and Distribution (OESD). The Energy Storage Program focuses on research and development (R\&D) of physical, chemical, and electrochemical energy storage systems. PNL supports these efforts by functioning as the Program Integration Center where analyses and information that help establish and evaluate R\&0 program objectives are provided. Thts annual report sumartzes the accomplishments of the TEA Program in FY 1985.

The mission of the TEA Program, which was initiated in June 1984, includes providing 0ESD with independent technical program evaluations, technology characterizations, and assessments and assisting in program information management. Specific objectives of the TEA Program include:

- Evaluating the technical state of the art for selected developing technologies.

- Providing comprehensive technology descriptions of selected energy storage systems, including technical, economic, and environmental aspects.

- Assisting DOE in improving the transfer of DOE-sponsored research to the private sector.

The TEA Program is divided into four elements: 1) Technical Assessments, 2) Cost Analysis, 3) R\&O PIanning, and 4) Technology Transfer/Market Analysis. These elements are integrated with on-going research activities at national laboratories, universities, and private firms to support decision makers and scientists in evaluating the progress of current research and in identifying key R\&D needs for future inclusion in the Energy Storage Program. The primary emphasis during the first year and a half of the TEA Program on technical assessments and R\&D planning; technology transfer and cost analysis efforts were initiated on a limited basis and will be expanded in FY 1986.

TEA PROGRAM HIGHLIGHTS FOR FY 1985

Specific highlights of recent activities in the TEA Program are outlined below.

Technical Assessments

The two thrusts of the Technical Assessments element include the development of analytical tools to assist energy storage program participants and assessments of storage technologies that are being considered for inclusion in the Energy Storage Program research activity. The following products or activities resuited from research efforts in these areas in FY 1985.

- Developed a menu driven microcomputer software for use in analyzing the economic viability of load-leveling battery systems.

- Completed a simulation analysis software package for use in predicting the impact of battery cell failure on battery system performance and $1 \uparrow f e$.

- Identified R\&D needs for corrosion research.

Cost Analysis

The goals of the Cost Anajysis element are to: 1) enhance coordination of battery cost activities, 2) improve the quality of battery system cost estimates, and 3) perform costoriented analyses which help the DOE establish goals, develop R\&D plans, and make decisions on R\&D emphasis. For FY 1985 the following accomplishments are reported:

- Reviewed existing cost analyses for zinc bromine, sodium-sulfur, and lead-acid batteries.

- Recommended improvements for existing cost data and for Energy Starage Program cost analysis guidelines. 


\section{R\&O Planning}

The goals of the Energy Storage R\&D planning element within the TEA Progran are to: 1) develop and update program planning documents, 2) coordinate program information managenent, and 3) implement technology monitoring support. Key FY 1985 activities included:

- Supported preparation of Energy Storage Five-year Research Plan.

- Developed a computerized data base that summarizes Energy Storage Program research.

- Designed and completed a mailing list for use by program participants.

- Developed a data base for Energy Storage Program reference material.

- Prepared a monttoring system for key Energy Storage Program activities.

Technology Transfer/Market Analysis

The goal of the Technology Transfer/Market Analysis element in the FY 1985 task was to assist in the transfer of Customer-Side-of-the-Meter (CSOM) battery-storage technolagy to the market-place. FY 1985 highlights included:

- Identified and contacted DOE offices with potential opportunities for utilizing CSOM.

- Identified and contacted battery and equipment manufacturers to assess their interest in CSOM.

- Contacted previous and ongoing CSOM study participants and DOE and other federal facility energy managers.

- Worked with the Princeton Plasma Physics Lab to determine the merit of installing CSOM battery storage. 


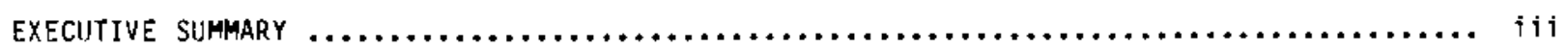

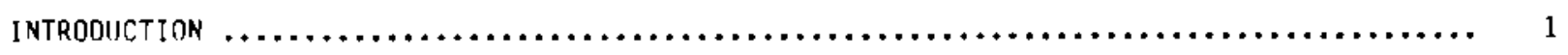

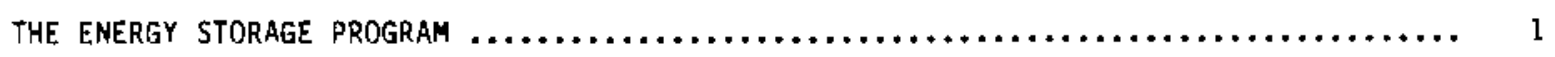

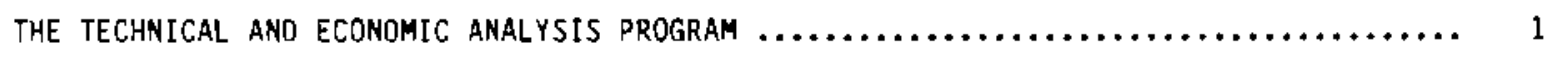

1. TECHNICAL ASSESSMENTS

BATTERY SYSTEMS REQUIREMENTS ANALYSIS $\ldots \ldots \ldots \ldots \ldots \ldots \ldots \ldots \ldots \ldots \ldots \ldots \ldots \ldots \ldots \ldots \ldots \ldots \ldots \ldots$

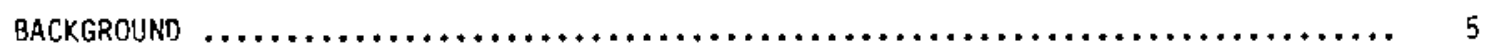

GOALS $\ldots \ldots \ldots \ldots \ldots \ldots \ldots \ldots \ldots \ldots \ldots \ldots \ldots \ldots \ldots \ldots \ldots \ldots \ldots \ldots \ldots \ldots \ldots \ldots \ldots \ldots \ldots \ldots . . \ldots$

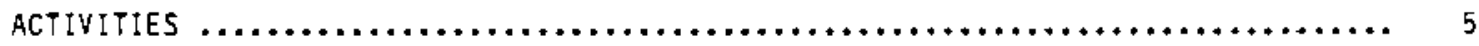

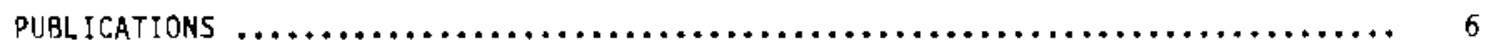

STATISTICAL ANALYSIS OF BATTERY FaILURES $\ldots \ldots \ldots \ldots \ldots \ldots \ldots \ldots \ldots \ldots \ldots \ldots \ldots \ldots \ldots \ldots \ldots$

BACKGROUND $\ldots \ldots \ldots \ldots \ldots \ldots \ldots \ldots \ldots \ldots \ldots \ldots \ldots \ldots \ldots \ldots \ldots \ldots \ldots \ldots \ldots \ldots \ldots \ldots \ldots \ldots$

GOALS $\ldots \ldots \ldots \ldots \ldots \ldots \ldots \ldots \ldots \ldots \ldots \ldots \ldots \ldots \ldots \ldots \ldots \ldots \ldots \ldots \ldots \ldots \ldots \ldots \ldots \ldots$

ACTIVITIES $\ldots \ldots \ldots \ldots \ldots \ldots \ldots \ldots \ldots \ldots \ldots \ldots \ldots \ldots \ldots \ldots \ldots \ldots \ldots \ldots \ldots \ldots \ldots \ldots \ldots \ldots . . \ldots$

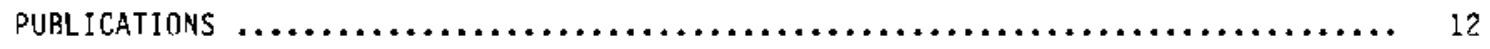

RESEARCH NEEDS FOR CORROSION CONTROL ANO PREVENTION IN ENERGY

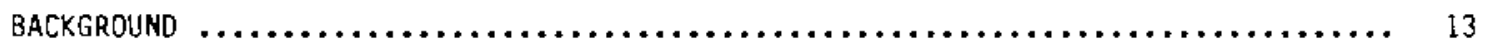

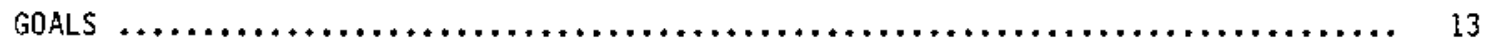

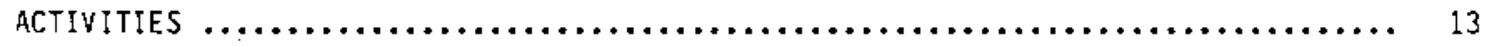

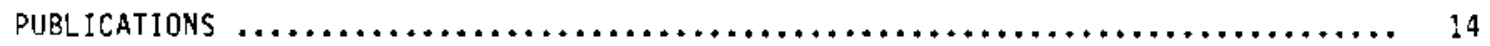

2. COST ANALYSIS

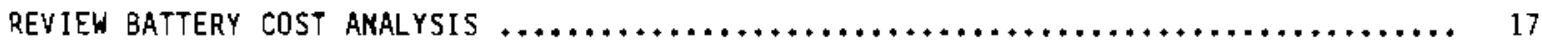

GOALS $\ldots \ldots \ldots \ldots \ldots \ldots \ldots \ldots \ldots \ldots \ldots \ldots \ldots \ldots \ldots \ldots \ldots \ldots \ldots \ldots \ldots \ldots \ldots \ldots \ldots \ldots \ldots \ldots \ldots 17$

ACTIVITIES $\ldots \ldots \ldots \ldots \ldots \ldots \ldots \ldots \ldots \ldots \ldots \ldots \ldots \ldots \ldots \ldots \ldots \ldots \ldots \ldots \ldots \ldots \ldots \ldots \ldots \ldots$

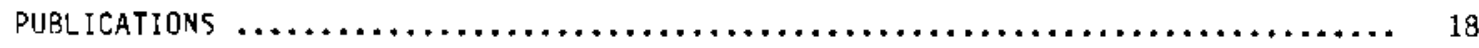

3. R\&D PLANNING

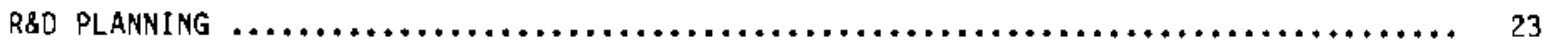

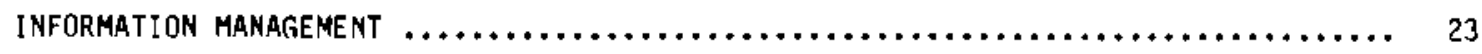

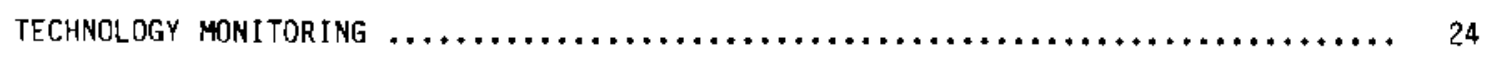

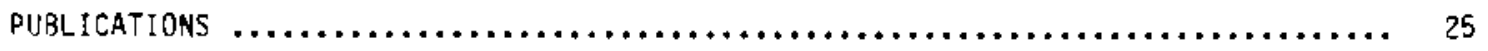


4. TECHNOLOGY TRANSFER/MARKET ANALYSIS

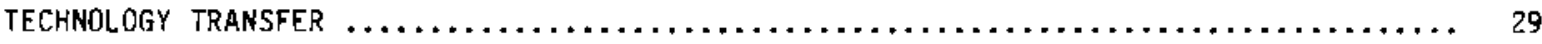

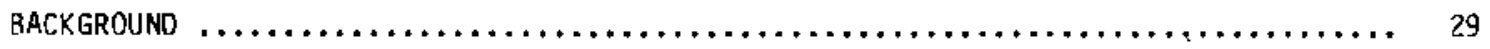

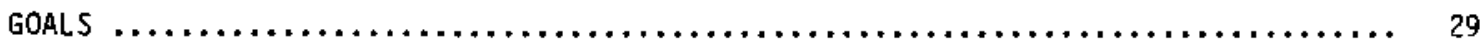

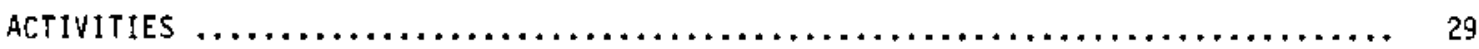

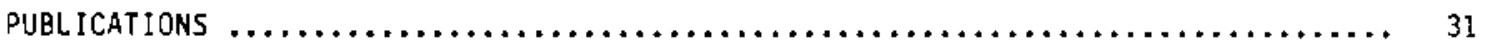




\section{FIGURES}

1. BATTERY SYSTEMS REQUIREMENTS ANALYSIS

FIGURE 1. Diagram of Customer-Side Load-Leveling Battery System $\ldots \ldots \ldots \ldots \ldots \ldots$

FIGURE 2. Illustration of the Impact of a Load Leveling Battery System

on a Customer's Power Load ................................ 6

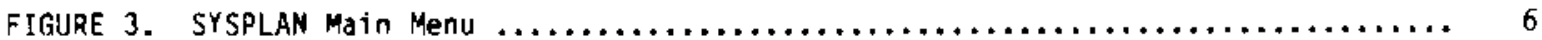

FIGURE 4, Economic Analysis Sumary Report $\ldots \ldots \ldots \ldots \ldots \ldots \ldots \ldots \ldots \ldots \ldots \ldots \ldots \ldots$

FIGURE 5. Net Cash Flow Graph,$\ldots \ldots \ldots \ldots \ldots \ldots \ldots \ldots \ldots \ldots \ldots \ldots \ldots \ldots \ldots \ldots \ldots \ldots \ldots \ldots$

FIGURE 6. Cumulative Cash Flow Graph $\ldots \ldots \ldots \ldots \ldots \ldots \ldots \ldots \ldots \ldots \ldots \ldots \ldots \ldots \ldots \ldots \ldots$

FIGURE 7, Example Graph of Payback Period Versus Expected Battery Life .......... 8

2. STATISTICAL ANALYSIS OF BATTERY FAILURES

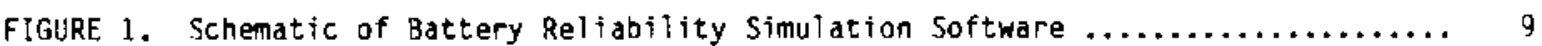

FIGURE 2. Example Weibull Distribution for Three Failure Modes ................

FIGURE 3. Simulation of Cycle Life Example Output $\ldots \ldots \ldots \ldots \ldots \ldots \ldots \ldots \ldots \ldots \ldots \ldots \ldots$

FIGURE 4. Flowchart of Reliability Analysis Package Operation .................. 12

3. COST ANALYSIS

FIGURE 1. Battery Cost Analysis Work Flowsheet $\ldots \ldots \ldots \ldots \ldots \ldots \ldots \ldots \ldots$

4. ENERGY STORAGE R\&D PLANNING

FIGURE 1. Example Energy Storage Projects Sumaries, Descriotions

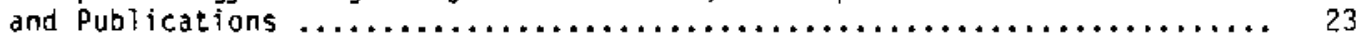

FIGURE 2. Fnergy Storage Mailing List Report of Database Contents ............ 24

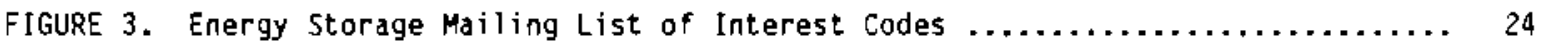


This document presents the 1985 Annual Report for the Technical and Economic Analysis (TEA) Program in the Energy Storage Program of the Office of Energy Storage and Distribution (OESD), U.S. Department of Energy (DOE). The TEA Program is a research effort conducted at Pacific Northwest Laboratory (PNL) to assist the OESD in identifying, analyzing, and assessing energy storage research and development (R\&D) needs and in providing technical management support for the Energy Storage Program. PNL has been designated as the Program Integration Center for all technical and economic assessment activities in the Energy Storage Program. In this capacity, PNL provides program analyses for hOE headquarters and also coordinates the technical and economic assessment studles performed by the other Taboratorfes involved in the Energy Storage Program.

This is the first annual report covering the activities and accomplishments of the TEA Program at PNL. It covers PNL work undertaken during FY 1985. Since this program is a multiyear effort, many of the activities summarized in this document will be continued during Fy 1986 and reported on at a later date.

\section{THE ENERGY STORAGE PROGRAM}

The DOE-OESD supports R\&D activities aimed at: 1) estabiishing the technical feasibility of innovative energy storage devices and processes and 2) encouraging the private sector to fully commercialize advanced energy storage technologies. The Energy Storage Program seeks to accomplish its goals by conducting fundamental and applied research and exploratory technology development of the most promising technologies that will fulfill the requirements of stationary energy storage for transportation and renewable-energy applications. The program considers midterm projects (1990 through 2000) that currently show high potential for substantial improvement in performance at reduced costs, such as sodium-sulfur and zinc-bromine batteries and thermal storage concepts, and long term projects (beyond 2000) such as metal-air batteries, fuel cells for transportation, and chemical-hydrogen batteries research, that promise superior performance but face major technical hurdles. The program also pursues a vigorous technology transfer effort to ensure that the private sector utilizes technologies developed under federal funding in their product development efforts.

\section{THE TECHNICAL AND ECONOMIC ASSESSMENT PROGRAM}

The Pacific Northwest Laboratory (PNL) was designated the Program Integration Center in June 1984. The primary role PNL plays is to provide independent technical and economic assessment, engineering analysis, and information management tools to the Director, OESn. In addition, PNL assists the OESD in its key effort of transferring technology to other federal agencies, state and local governments, and private industry. The TEA Program of PNL provides program managers at 0ESD with critical technical, economic, and technology transfer information required for the efficient management and direction of their R\&D programs.

Specific objectives of the TEA program include:

- Evaluate the technical state of the art for selected developing technologies.

- Provide comprehensive technology descriptions of selected energy storage systems, including technical, economic, and environmental aspects.

- Assist DOE in improving the transfer of DOE-sponsored research to the private sector.

The TEA Program at PML is divided into four elements: 1) Technical Assessments, 2) Cost Analysis, 3) R\&D Planning, and 4) Technology Transfer/Market Analysis. Tasks performed under the Technical Assessments element provide assessments of l) promising storage technologies that are currently not within the scope of Energy Storage Program research activity and 2) research toois that assist Energy Storage Program participants. The Cost Analysis element was established to coordinate Energy Storage Program cost analyses, establish program goals and guidei ines for future cost analysis work, and maintain current cost data in a format that is easily accessible to program participants and decision makers. The goal of the R\&D Planning Element is to assist DOE in collecting and evaluating information on technologies and markets that will be 
used in planning for the Energy Storage Program R\&D efforts. The Technology Transfer/Market Analysis element focuses on improving transfer of program research results to the private sector and, upon evaluation of storage technology markets, identifying key R\&D requitrements.

Since the TEA Program began in late 1984, the main emphas is of the program has been on technical and cost andysis. Highlights include identification of R\&D needs for corrosion research, development of software to evaluate the impacts of cell reliability on battery performance and cycle life, creation of microcomputer software to aid 11fe-cycle cost analysis of load-leveling battery installations, and a review of the status of battery cost information. Initial efforts in R\&D planning and technology transfer were also conducted, including the identffication of public facilities that are candidates for customer-side-of-the-meter (CSOM) load-leveling installations, preparation of multi-year planning documents, and organization of technical workshops and contractor conferences. These and other activities are summarized in following sections. 


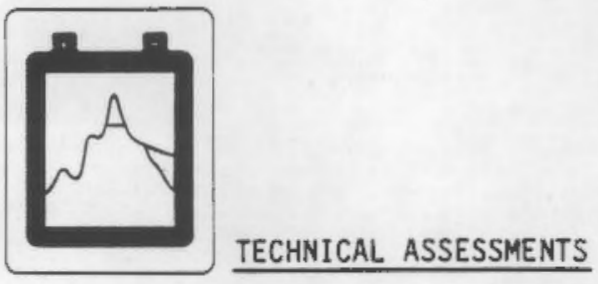

The DOE Energy Storage program over the last several years has evaluated a large number of energy storage technologies, developed promising technologies, and successfully transferred new technologies to the private sector. This process involves continuous iteration between technology development and technical and economic assessment. The lead centers, Lawrence Berkeley Labs and Sandia National Laboratory, provide the leadership in the technology development effort for the Energy Storage Program. PNL undertakes the technical and economic assessment of the technologies.

In FY 1985 specific tasks involved in this area included:

- Battery Systems Requirements Analysis (Task Manager: C. Hostick)

- Statistical Analysis of Battery Failures (Task Manager: C. Hostick)

- Research Needs for Corrosion Control and Prevention in Energy Conservation Systems (Task Manager: J. Hurwitch).

A description of the accomplishments in these tasks follows. 


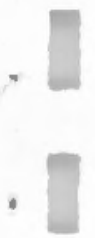

.

I<smiles>[124IH]</smiles>

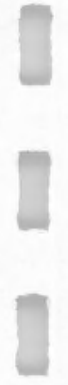

(1)

]

(1)

.

1

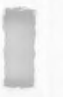

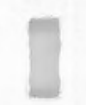

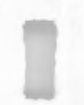

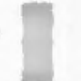

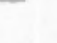

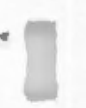




\section{BATTERY SYSTEMS REQUIREMENTS ANALYSIS}

\section{BACKGROUND}

The purpose of this work was to develop an economic analysis tool that would aid in feasibility studies of customer-side loadleveling battery systems. The result was a microcomputer-based software package that is capable of completing a life-cycle cost analysis of battery load-leveling installations. This package is designed to be used to rapidiy detemine the economic feasibility of battery load-leveling for a wide variety of facilities. The results of this analysis can be used to decide if detailed engineering studies are warranted.

Initial analysis of the economics of customer-side load-leveling battery systems indicates that these systems could be economically attractive in a wide range of applications. The purpose of a load-leveling battery system is to reduce a customer's monthly electrical demand charge by reducing the maximum power load supplied by the utility during the customer's peak demand period.

Load-leveling battery system equipment consists of a large array of batteries, a converter that changes $A C$ current into $D C$ current (or DC current into AC current), and balance-of-plant equipment and facilities required to support the battery and converter system. A diagram of a load-leveling system is shown in Figure 1.

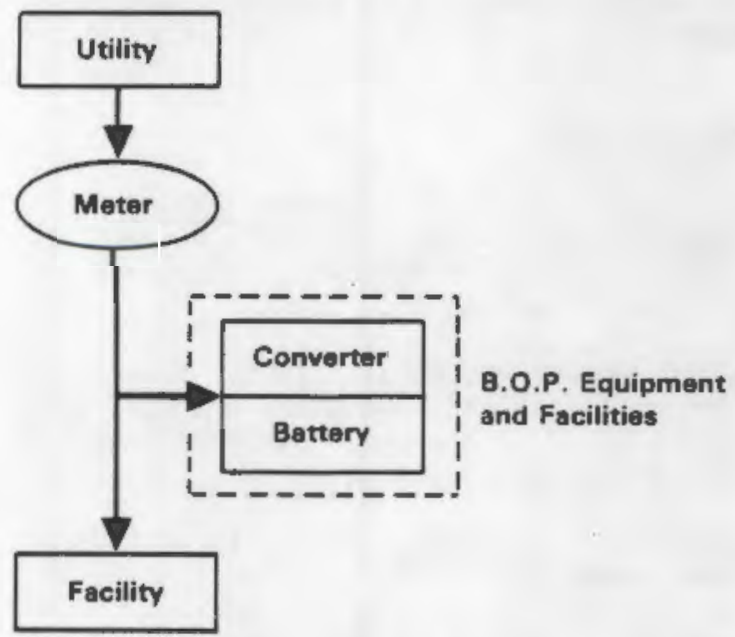

FIGURE 1. Diagram of Customer-Side LoadLeveling Battery System
The impact of a load-leveling battery system on a customer's power load is shown in Figure 2. The system is installed on the customer's side of the meter and is controlled and operated by the customer. The battery system charges during a customer's off-peak power requirement periods and discharges during the customer's peak demand periods. The economic feasibility of a load-leveling battery system depends largely on the customer's load profile. As the primary economic benefit of load-leveling is a reduction in customer's monthly demand charge, only those customers with a significant demand peak will find a load-leveling system economically attractive. Load shape requirements, utility rate structures, and battery equipment cost and performance information serve as the bases for detemining if a load-leveling battery system is economically feasible for a particular installation. Life-cycle costs for loadleveling system hardware include all costs associated with purchasing, installing, and operating battery, converter, and balanceof-plant facilities and equipment.

GOALS

The goal of the Battery Systems Requirements Task was to develop a tool that would facilitate the transfer of customer-side battery storage technology to the marketplace. Specifically, this task sought to develop a menu-driven microcomputer-based tool that could be used to perform preliminary economic analysis of potential customer-side load-leveling systems. This tool would be used to show customers the benefits of load-leveling using battery storage and to determine if more detailed engineering feasibility studies are warranted.

\section{ACTIVITIES}

A load-leveling system analysis software package entitled 'SYSPLAN' was developed using commercially available Lotus 123 software. To run the software, a user needs an IBM-PC with at least $256 \mathrm{~K}$ internal memory and two floppy disk drives (or one floppy disk drive and one hard disk drive). In addition, a copy of the Lotus 123 system software copyrighted by the Lotus Development Corporation is needed.

The SYSPLAN Software provides a complete life-cycle costing analys is of all the major components of a customer-side load-leveling battery system. Using the main menu shown 


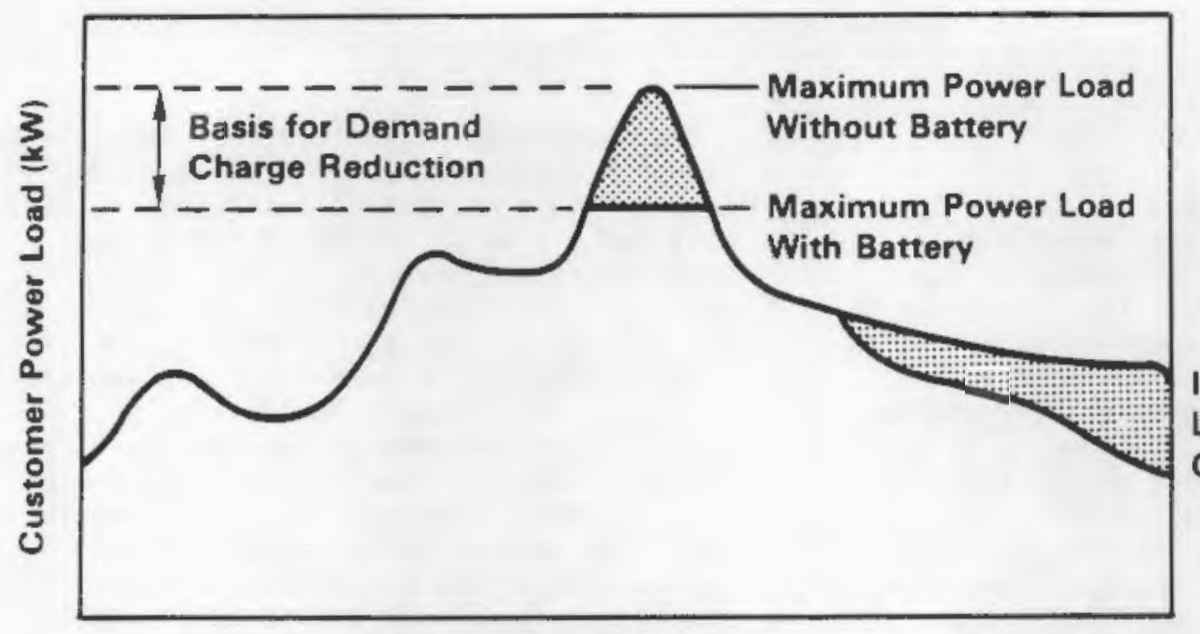

Increased power Load Required to Charge Battery

\section{Time of Day}

FIGURE 2. Illustration of the Impact of a Load-Leveling Battery System on a Customer's Power Load

in Figure 3 , the user specifies all relevant battery operating requirements and cost data.

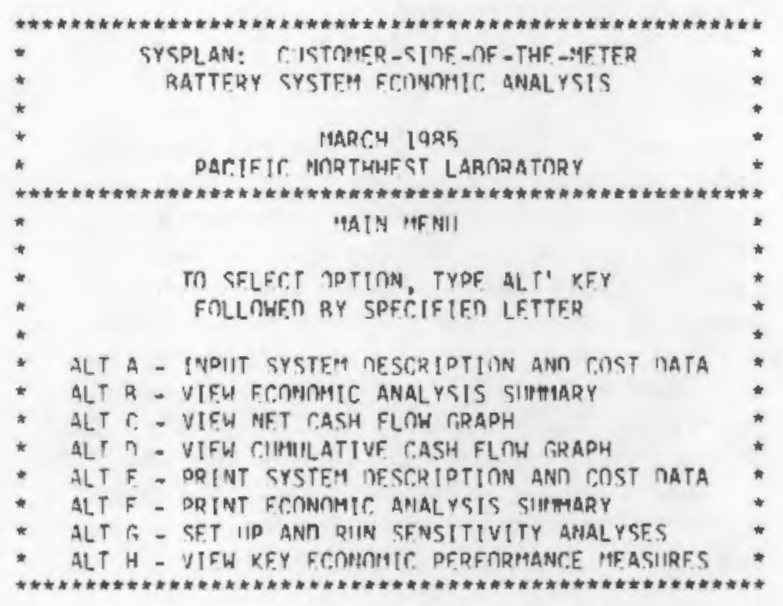

\section{FIGURE 3. SYSPLAN Main Menu}

SYSPLAN output is presented in both tabular and graphical form. The economic analysis summary of all system related cash flows for the load-leveling system being analyzed is shown in Figure 4 . Figures 5 and 6 are graphical representations of net and cumulative cash flow, respectively. The dips in the graph of net cash flow represents per1odic battery replacement.

Also included in the software package is an optional battery system sizing routine and a built-in sensitivity analysis package for key battery system parameters. The optional battery system sizing routine aids users in making initial choices about the size of the system that is economically feasible for their application. The builtin sensitivity analysis package can be used to measure the impact of changes in key battery components on expected system economics. For example, Figure 7 shows how system payback period varies with increasing battery system cycle life.

Software and documentation are available for distribution and can be obtained by contacting $\mathrm{C}$. J. Hostick at Pacific Northwest Laboratory, Richland, Washington [telephone (509)376-4154]. Future activities include preparing a summary of relevant battery cost information to assist in economic scoping studies.

\section{PUBLICATIONS}

Hostick, C. J., et al. 1985. SYSPLAN: Model Documentation and User's Guide. PNL-5595, Pacific Northwest Laboratory, Richland, Washington.

Hutchinson, R. A., et al. 1985. "Battery System Sizing and Investment Analysis with Lotus 123." Presented at ORSA/TIMS 1985 Joint National Meeting, Atlanta, Georgia.

Hurwitch, J. W. 1985. "Analys is of Load Management Options for Utility Custamers on the Customer Side of the Meter." Presented at Seventh Battery and Electrochemical Contractor's Conference, Washington, D.C. 


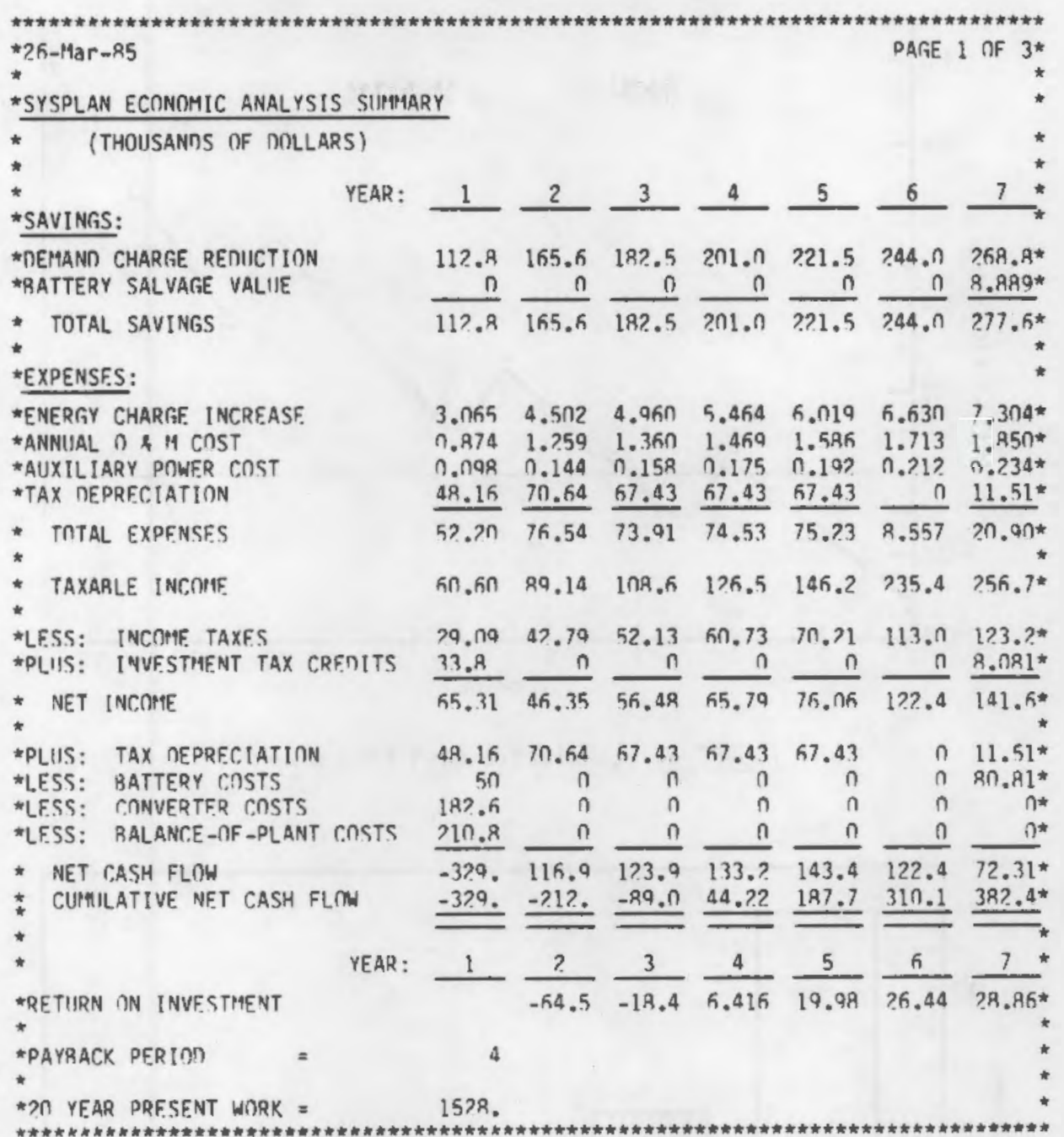

FIGURE 4. Economic Analysis Summary Report

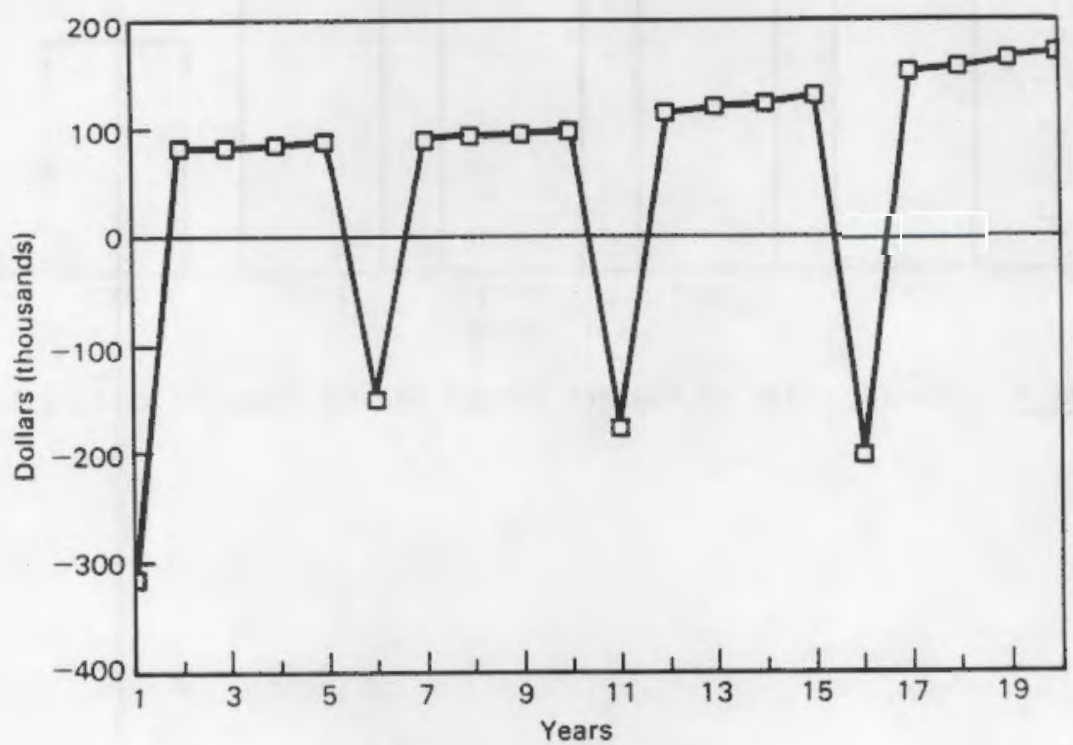

FIGURE 5. Net Cash Flow Graph 


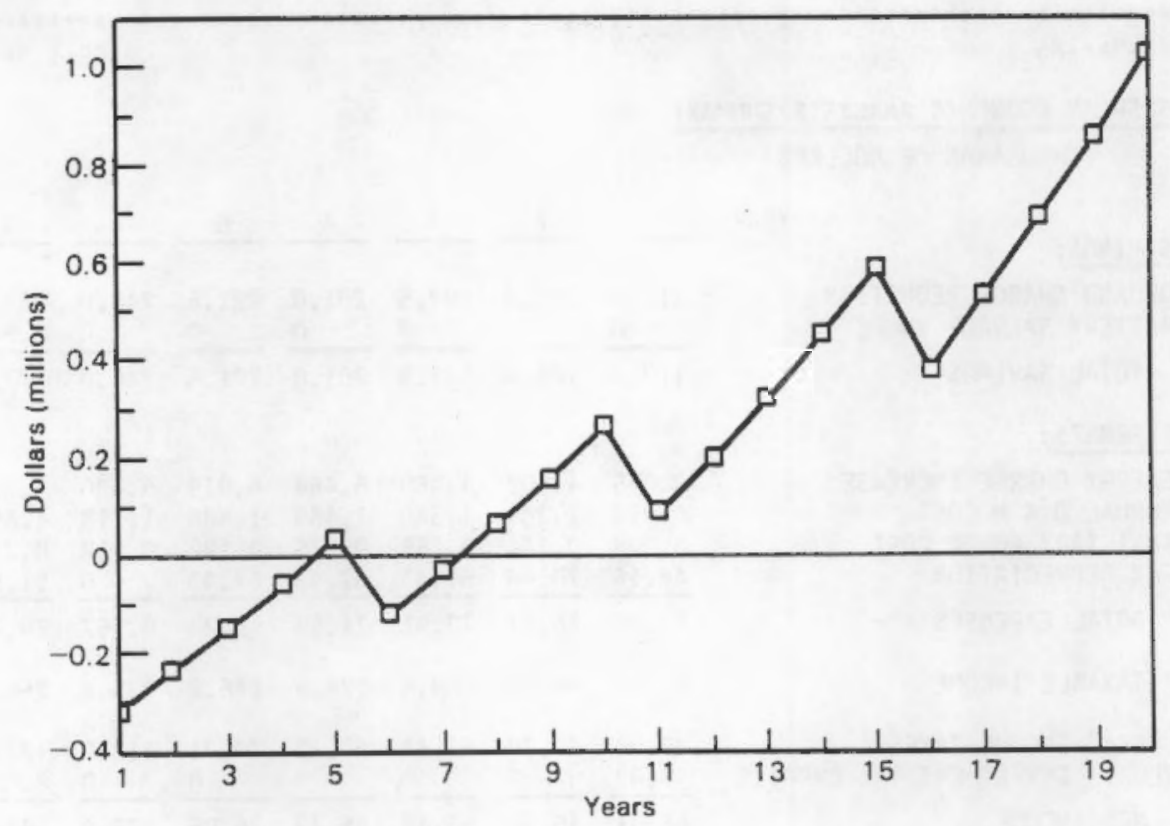

FIGURE 6. Cumulative Cash Flow Graph

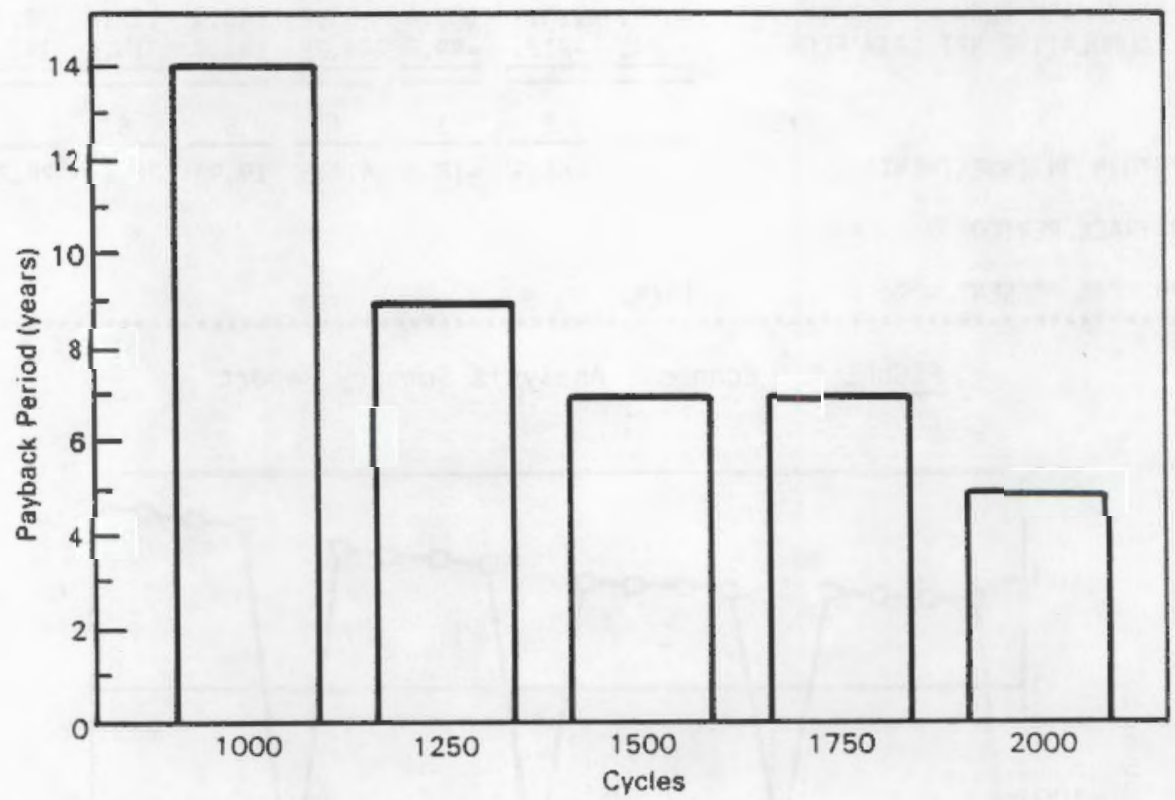

FIGURE 7. Example Graph of Payback Period Versus Expected Battery Life 
BACKGROUND

Battery developers cannot afford to build and test all battery configurations capable of meeting a particular mission. Therefore, some type of analysis tool is needed that can be used to identify superior battery configurations before actual testing begins. A logical approach is to build a computer model of battery performance based on available bench-test data of individual cells. However, developing accurate and useful models to estimate battery behavior is also expensive and often beyond the scope of a battery developer's budget.

Key considerations in evaluating the reliability of advanced battery technologies include 1) the impact of cell failures on battery performance and 2) cycle life. The purpose of this task was to develop interactive microcomputer-based software that would translate limited bench-test data into an estimate of battery performance and life. The product of this task can be used to identify improved battery configurations for specific applications and to provide a mechanism for quantifying reliability improvements into estimates of extended battery $1 \mathrm{ife}$.
GOALS

The goal of this task was to develop microcomputer-based software capable of translating battery configuration and cell reliability into estimates of battery performance and life. Upon completion, the software is to be freely distributed to battery developers and battery research planners. Intitial software development efforts focused on the area of sodium-sulfur cells since that is an advanced technology area in which 1 inited data are available concerning the performance of large battery configurations. Furthermore, the need to improve sodium-sulfur cell reliability is a key concern, and quantifying reliability improvements into estimates of additional cycle life will assist in design improvement studies.

\section{ACTIVITIES}

A schematic of the microcomputer-based battery reliability simulation software completed under this task is shown in Figure 1. The software package includes three main components: 1) the failure distribution tutorial, 2) the simulation-of-cycle-life

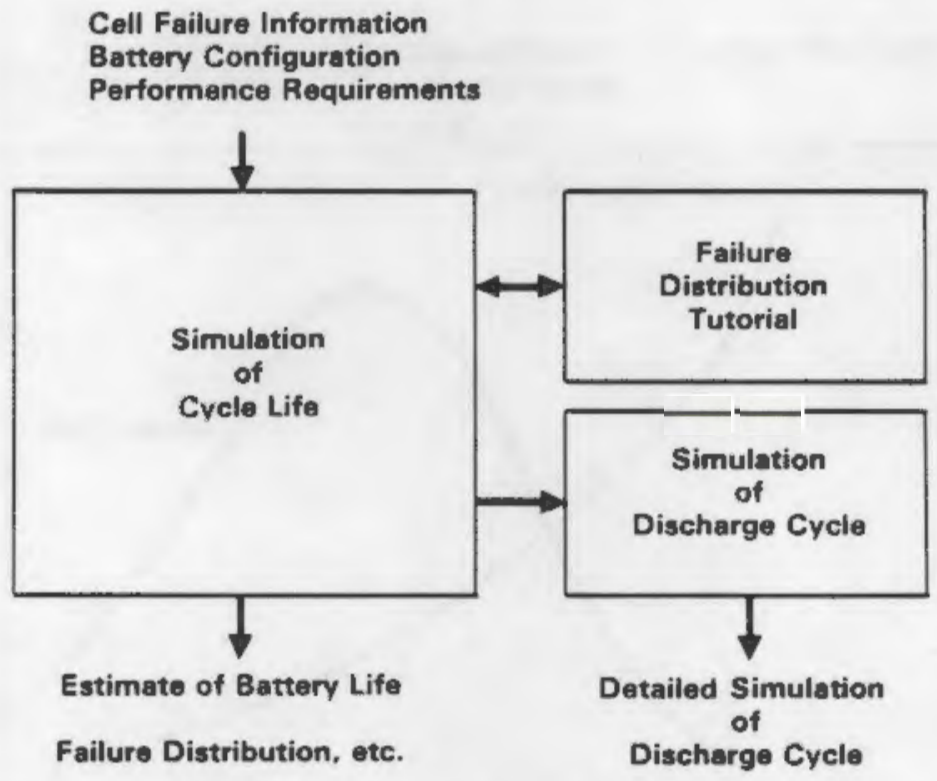

FIGURE 1. Schematic of Battery Reliability Simulation Software 
component, and 3) simulation-of-dischargecycle component. The failure distribution tutorial explains to the user how the distribution of battery cell failure is modeled. The simulation of cycle life provides an approximate estimate of battery cycle life, based on cell failure information, battery configuration, and performance requirements. The simulation-of-dischargecycle component can be used to estimate battery performance for a specified cycle and can serve to provide a more precise estimate of battery life. The failure distribution tutorial explains the Weibull parameter and how it is used.

The Weibull distribution has been widely applied in representing the failure behavior of electronic components and systems, partly because of its flexibility in representing a wide range of failure patterns. It is flexible because distribution parameters can be adjusted to match the behavior of the system. The three separate parameters that identify the Weibull distribution are scale, shape, and location. All three Weibull parameters affect the measure of the central tendency of the distribution, and the ratio of the shape parameter to the scale parameter affects the dispersion. The location parameter is also known as the threshold parameter and represents a time before which failures cannot occur.
The flexibility of this distribution is indicated in Figure 2, which shows two example Weibull distributions. The distributions represent examples of infant-mortality, and cell-aging failure modes. The distribution parameters were adjusted to accommodate differences in these failure modes. For example, freeze-thaw failures have a more even distribution across the cell life, and cell-aging failures occur predominately during the latter portion of a cell's life.

Simulation of cycle life is a microcomputer application of similar work completed by Science Applications, Inc. for EPRI in 1982. Basically, the modeling approach is a Monte Carlo simulation of battery life (measured in cycles) that produces a distribution of expected battery life. An example distribution of the simulation of cycle life output is shown by Figure 3 .

The simulation-of-discharge-cycle model estimates detailed battery performance for a specified cycle. For example, if cycle 1630 is specified, the performance of the battery configuration containing all the individual cell failures that can be expected to occur between cycles 0 to 1630 is estimated. The model of sodium-sulfur battery performance is based on a current-voltage depth-of-discharge (DOD) relationship. Phenomenological

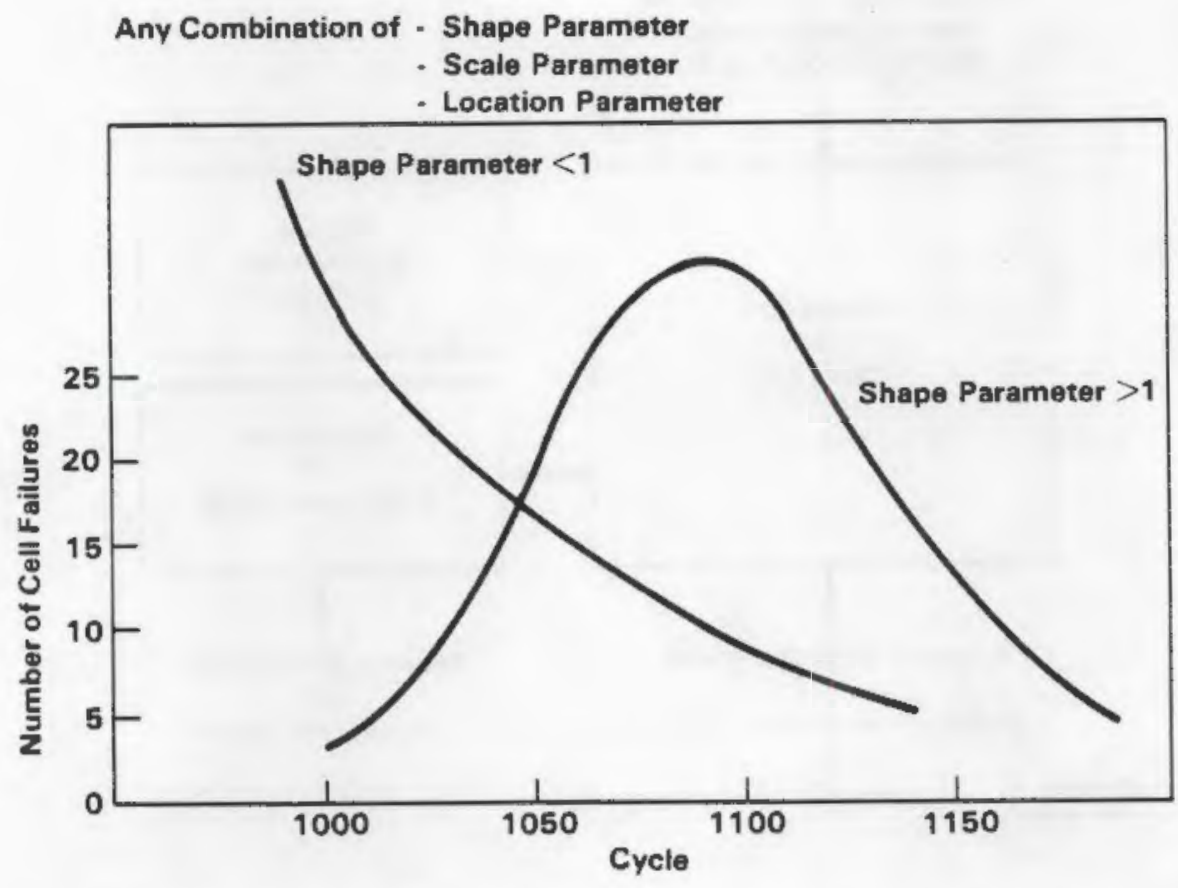

FIGURE 2. Example Weibull Distribution for Three Failure Modes 


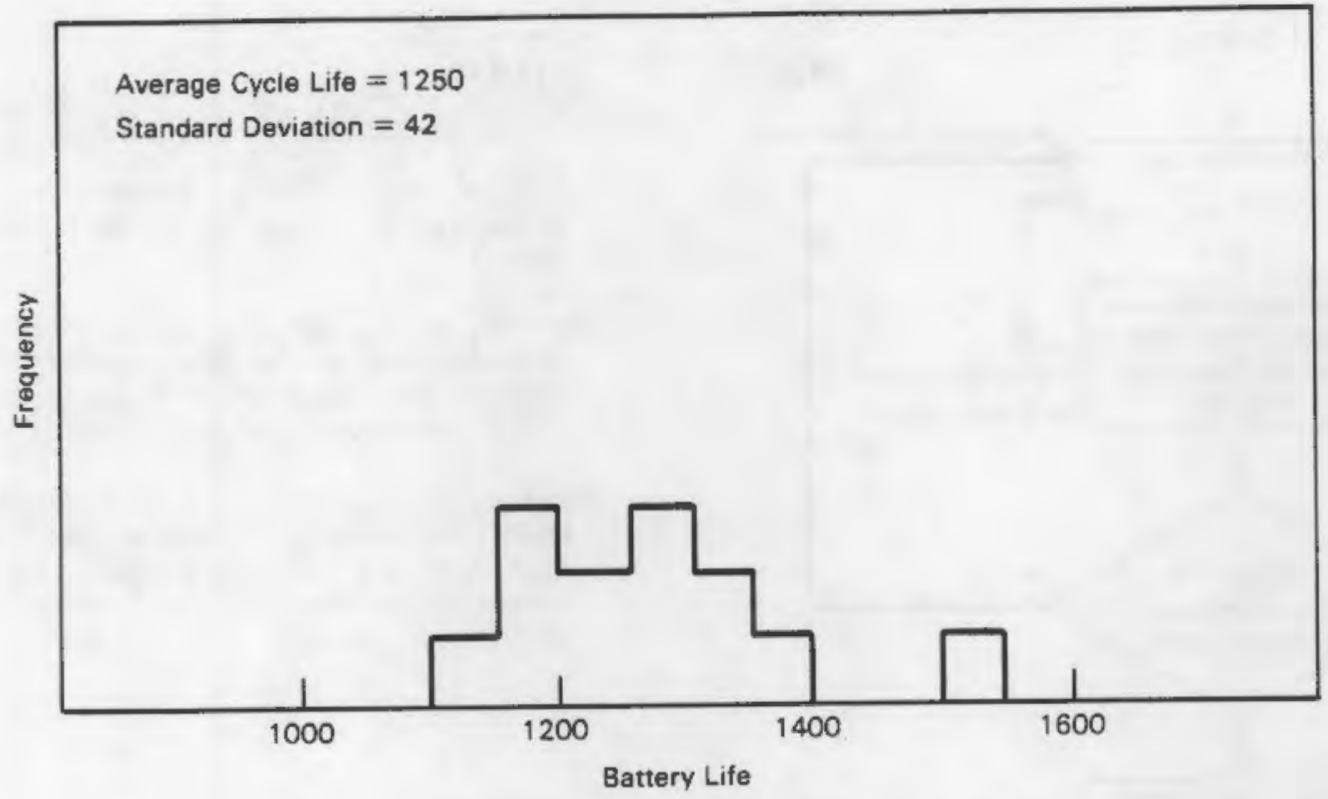

FIGURE 3. Simulation of Cycle Life Example Output

cell modeling is the process of identifying the current-voltage 000 relationship through curve fitting of bench-test data. The general current-voltage DOD relationship is:

$$
\begin{aligned}
& V=E-I R, q<=0 / 2 \\
& V=E-I R-A(q-Q / 2), q>Q / 2
\end{aligned}
$$

$$
\text { where } \begin{aligned}
V & =\text { cell voltage } \\
E & =\text { open circuit cell voltage } \\
I & =\text { cell current } \\
R & =\text { cell internal resistance } \\
A & =\text { modeling constant } \\
q & =\text { value of DOD before (in amp } \mathrm{hr} \text { ) } \\
Q / 2 & =\text { value of } D 0 D \mathrm{q} \text { at } 1 / 2 \text { discharge. }
\end{aligned}
$$

This model of an $\mathrm{Na}-\mathrm{S}$ cell accurately represents the physical phenomena of cell voltage staying constant while the cathode is two phase $\left(5 \mathrm{~S}+2 \mathrm{Na}^{+}+2 \mathrm{e}+\mathrm{Na}_{2} \mathrm{~S}_{5}\right)$ and the development of a single-phase Naxs cathode reagent produced as a result of continuing reaction of $\mathrm{Na}$ with the sulfur-containing cathode on discharge.

PNL tested the accuracy of the above model through a preliminary validation based upon the modeling parameters $A, R, E$, and $Q / 2$. The results were compared to bench-test data for similar, constant discharge conditions.

To use the complete modeling package a user would first use the failure distribution tutorial to determine the type of distribution parameters required. The user would then reyiew the data for the battery system being modeled to determine these parameters. A flowchart of how the simulation of cycle life interacts with the detailed discharge model is shown in Figure 4. The user estimates battery cycle life using the simulation of cycle life. The estimate of battery life would then be verified by running the detailed discharge model near the end of expected battery life. For example, if expected battery life is 1536 cycles, the detailed model would be run at 1536 to see if the battery was or was not meeting its mission. If the battery performance was found to be adequate at 1536 cycles, the simulation-of-cycle-life model would be repeated using more accurate performance requirements. If battery performance was found to be inadequate at 1536 cycles, earlier cycles would be tested to determine specifically the cycle of failure. If the battery configuration/cell reliability is inadequate to meet the hattery mission, the experiment can be redefined and the process repeated. Once a configuration has been found to be adequate, additional runs can be obtained to generate descriptive battery performance statistics.

Future work consists of model yalidation, and extending the detailed discharge model to include lead-acid and zinc-bromine battery systems. In addition, the software will be distributed to several battery developers before the final package is completed to ensure the adequacy of the software. 


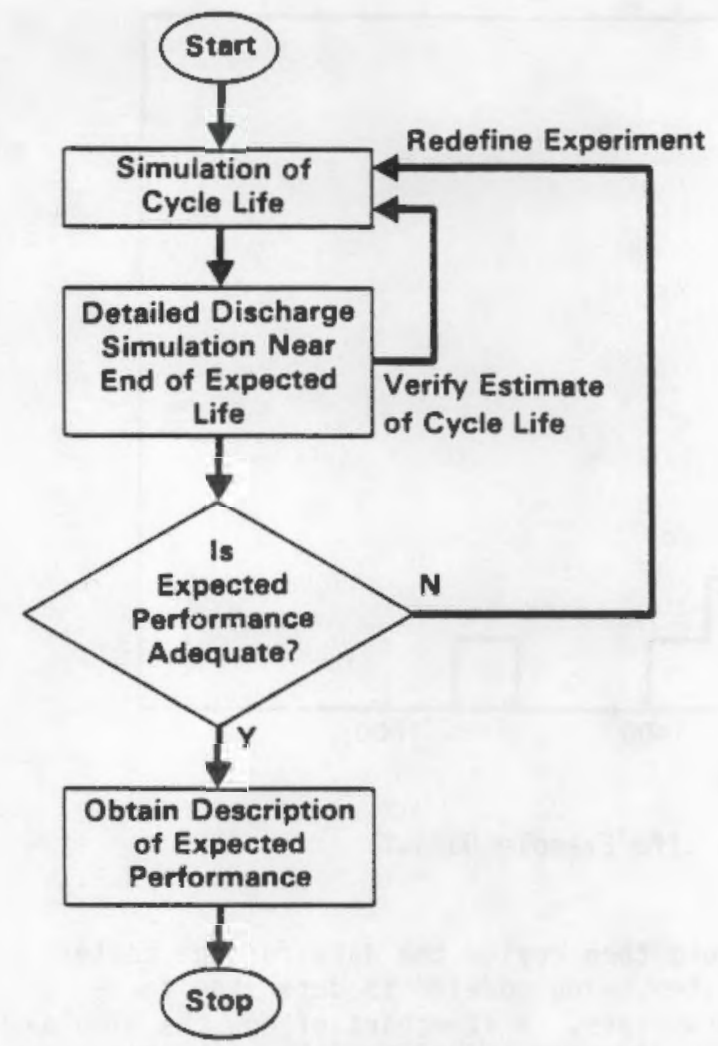

PUBLICATIONS

Hostick, C. J., et al. 1985. Reliability Modeling System for Analys is of Advanced Battery Technologies. Pacific Northwest Laboratory, Richland, Washington. (In preparation. Expected to be published in 1986.)

Hostick, C. J., et al. 1985. "Reliability Modeling System for Analysis of Advanced Battery Technologies." Presented at 20th IECEC Conference, Miami, Florida.

Hostick, C. J., et al. 1985. "Reliability Model for Battery Technologies." Presented at the Seventh Battery and Electrochemical Contractors' Conference, Washington, D.C.

FIGURE 4. Flowchart of Reliability Analysis Package Operation 
RESEARCH NEEDS FOR CORROSION CONTROL AND PREVENTION IN ENERGY

\section{CONSERVATION SYSTEMS}

\section{BACKGROUND}

In the United States approximately 4 percent of the Gross National Product each year is lost because of corrosion and its effects. For example, in 1982 the cost of corrosion was about $\$ 122$ billion, of which close to $\$ 17$ billion could have been avoided by using the best available technology. The opportunity for greater savings exists if new or improved corrosion control and prevention measures could be implemented. The rationale for spending funds on corrosionrelated $R \& D$ activities is easily understood in terms of the dollar savings in energy and materials to reduce excess capacity, replace lost product, lower maintenance costs, improve safety, and all the other factors influenced by corrosion.

To place the problem in perspective, it is of interest to review some of the 1982 estimates for corrosion in the U.S., along with estimates of the avoidable costs:

\section{ACTIVITIES}

Following an introductory session in which some of the key problems and research in progress in the buildings and structures, transportation and industrial sectors were reviewed by guest speakers, the participants from government, industry and academia assembled into four technical discussion groups. Each group leader had the responsibility for addressing one of the following topics: 1) localized corrosion, 2) general corrosion, 3) high temperature corrosion, and 4) corrosion control and prevention. Research needs were identified, discussed, and then assigned a figure of merit in terms of their relevancy, urgency, feasibility and impact. Later the results from the four groups were integrated, and the findings are presented in a report entitled Research Needs for Corrosion Control and Prevention in Energy Conservation Systems.

Some 44 corrosion control and prevention topics were identified as having a high

\begin{tabular}{|c|c|}
\hline $\begin{array}{l}\text { Avoidable } \\
\text { Cost, } \$ 10^{6} \\
\end{array}$ & $\begin{array}{c}\text { Potential } \\
\text { Saving in Quads } \\
\end{array}$ \\
\hline 1,360 & 0.26 \\
\hline 210 & 0.04 \\
\hline 370 & 0.07 \\
\hline 4,500 & 0.87 \\
\hline 10,500 & 2.03 \\
\hline 16,940 & 3.27 \\
\hline
\end{tabular}

priority for consideration for funding. Another 35 topics were identified as having a medium priority for funding.

When classified according to corrosion phenomenon, the areas that should receive the most attention are molten salt attack, crevice corrosion, stress-corrosion cracking, erosion-corrosion, pitting attack, intergranular attack and corrosion fatigue. When classified according to the sector or system involved, those which should receive the most attention are chemical processes, transportation, buildings and structures, electric power generation, and batteries and fuel cells.

A common theme among the discussion groups was the apparent need to establish data bases for specific corrosion phenomena, then make the information available to the designers, engineers and researchers so that they could incorporate the data into products and 
processes. This type of research need consistently was rated as falling in the high priority category. Eventually, expert systems that could be used with CAD/CAM facilities at the design stage should be developed. To accomplish this, more work would have to be done on modeling corrosion phenomena and interactions between materials and their environment. The work recently initiated by the National Bureau of Standards was cited as an example of the type of data base needed and the useful output that could be generated.

Two of the important areas identified for funding consideration, in terms of the size of the cost savings which would result if R\&D efforts were successful, were the corrosion of steel in concrete and in vehicles, A common link between these two is the aggressive role the chloride ion, which is present in highway deicers, plays in corrosion.

Other important areas included high temperature oxidation, erosion-corrosion, molten salt and liquid metal attack. With the first three topics especially, degradation occurs through the breakdown of coatings under complex conditions. Additional work needs to be done on investigating the simultaneous reactions that occur in electricity generating equipment and electrometallurgical processes.

It was recommended that DOE consider funding R\&D in the area of corrosion control and prevention for energy conservation systems, and provide funding or support for establishing data bases and technology transfer procedures. A modest initial budget was recommended, and programs should be selected on the basis of the screening criteria described in the workshop. The availability of financial resources in the various sectors should also be considered. For example, corrosion control and prevention methods have received much attention in the electricity generation and automobile industries and the Electric Power Research Institute (EPRI) could possibly sponsor R\&D in this area. However, in other industries, such as the chlor-alkali industry and the pulp and paper industry, there are opportunities for solving major corrosion problems, and thereby conserving energy and materials. However, resources are limited particularly in the chlor-alkali industry where production is relatively low and prices are depressed. In cases like the chlor-alkali industry, DOE can provide the incentive for conducting necessary research.

The DOE can also play a supportive role by developing instrumental techniques and testing methodologies, which can be applied to a wide range of corrosion-related problems, or by focusing on very specific areas, such as molten salt/liquid metal corrosion, and providing a broader perspective to the problem.

\section{PUBLICATIONS}

Brooman, E. W. and J. W. Hurwitch. 1985. Research Needs for Corrosion Control and Prevention in Energy Conservation Systems. PNL-5457, Pacific Northwest Labora-

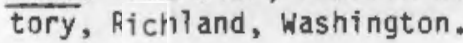




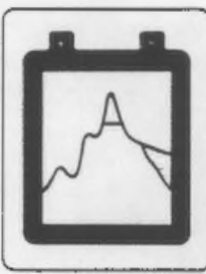

2. COST ANAL.YSIS

Cost and economic analysis is an important part of most technology development programs as both technical and economic barriers must be overcome to achieve implementation in competitive market applications. In addition, ill-defined costs contribute to economic risk which inhibits technology implementation.

Accurate knowledge of costs serves to reduce econonic risk and improve the prospects for eventual implementation. In addition, accurate knowledge of costs can be extremely helpful for directing research priorities while technology is being developed. The general purpose of this task, then, is to enhance the quality of battery cost data in order to minimize perceptions of economic risk and help provide direction for R\&D planning.

The specific long-term goals of the TEA Program's Battery Cost Analysis Task are to: 1) enhance coordination of battery cost analysis activities, 2) improve the quality of battery system cost estimates, and 3) perform cost-oriented analyses which help the DOE establish goals, develop R\&D plans, and make decisions on R\&D emphasis. 

GOALS

Task objectives for FY 1985, and the focus of work described in this report, were to identify the current status of battery system cost analyses and make recommendations for future work in this area.

\section{ACTIVITIES}

Cost analyses for zinc-bromine, sodiumsulfur, and lead-acid batteries were reviewed. Zinc-bromine and sodium-sulfur batteries were selected because of their advanced design nature and the high level of interest in these two technologies. Leadacid batteries were included to establish a baseline representative of a more mature technology.

The most recent and thorough cost analyses of zinc-bromine, sodium-sulfur and lead-acid battery systems were sought for the review. Zinc-bromine and sodium-sulfur battery developers were contacted to ensure that the latest and/or most detailed analyses were being considered. Current manufacturers of lead-acid batteries were not contacted since interest was primarily oriented toward leadacid battery cost analyses that were completed during the earlier development stages of that technology. The lead-acid battery cost analyses served as a benchmark for comparison with zinc-bromine and sodium-sulfur battery cost analyses. The time frame of the analysis process iimited PNL's review to publications available by the end of 1984 .

An essential part of the review process was the development of a list of cost characterizing information relevant to battery systems. The list defines the type of information and level of detail that should be available to fully and adequately evaluate the costs of a battery system. Following a standard set of estimating guidelines would benefit the cost analysis process by providing more consistency between estimates, more complete estimates, more accurate estimates, and better reproducibility by independent parties. All of these factors would give greater credence to the estimated costs and enhance their usefulness to the R\&D planning process.

The list of cost characterizing information is headed by six categories: system description summary, design specifications, performance specifications, manufacturing cost, installed system cost, and life-cycle cost. System description and design/performance specifications define the system being costed and serve to identify cost differences among systems stemming from differences in system boundary, design type, and performance characteristics. Cost estimating ground rules and assumptions are defined within each of the cost categories. Each category addresses the costing premises and emphasizes the inclusion of all cost components pertinent to manufacturing, installed system, and life-cycle costs, respectively.

Each of the battery system cost analyses reviewed was evaluated with regard to the system completeness and level of detail associated with the cost characterizing information described above. The emphas is of the evaluation was oriented toward determining whether the information presented would allow an independent reconstruction of the estimate and/or reconciliation of esti mates from different sources. No attempt was made in this study to validate any single estimate or reconcile two or more estimates to common assumptions.

In general, cost analyses for mature leadacid batteries have been more numerous, more complete, and have greater detail than for either zinc-bromine or sodium-sulfur batteries. Several cost analyses completed for lead-acid batteries could, with minor modifications, serve as examples of expected levels of detail and completeness for other batteries. The quality of the economic analyses combined with greater commercial experience has created uncertainty in estimated costs for lead-acid battery systems.

The lack of maturity in zinc-bromine and sodium-sulfur battery cost analyses, when compared to lead-acid batteries, can be partly attributed to the differences in design maturity. The level of design detail available provides an upper limit to the level of cost detail possible. Still, improvements could be made even at the current level of design maturity. Problems currently facing zinc-bromine and sodium-sulfur battery cost analyses are briefly discussed below:

- Cost information is fragmented. No single report addresses each of the six major categories of cost characterizing information. Rapidly changing designs make it difficult to trace costs presented in one report to design information presented in another report.

- Completeness of estimates varies significantly. Incomplete estimates inevitably Tead to underestimated costs. 
Differences in completeness also makes direct comparison of cost estimates impossible.

- Many estimates lack supporting details. Lack of detail makes an independent reproduction of the estimate impossible, thus lowering credibility. For example, descriptions of manufacturing operations, floor space requirements, and equipment were often limited, if they existed at all.

- Very few installed system or life-cycle cost estimates. Estimates of installed system and life-cycle costs were limited to three sources for zinc-bromine batteries and two sources for sodiumsulfur batteries.

The following observations apply to all battery systems. Converter costs were found to vary widely with assumptions made regarding power level, design, and production volune. Converters for large battery systems are currently in their own developmental phase and suffer from cost uncertainty that is comparable with that for the batteries themselves. Finally, it is important to remember that the technical feasibility, the probability a battery will work as advertised, may be significantly different for two batteries that are estimated to have similar installed-system and life-cycle costs. Two systems must provide a similar service in order for cost comparisons to be meaningful.

In view of the observations summarized above, the following recommendations are offered as a means to improve battery cost analyses:

1. Develop standard guidelines which establish the system components to be included, the appropriate level of detail in description, and ground rules and assumptions for estimating manufacturing, installation, and life-cycle costs. The implementation of guidelines would serve to standardize the economic analysis procedure and focus on cost differences attributable to differences in battery type or design.

2. Spend more effort characterizing installed system and life-cycle costs. Bal ance-of-plant, battery-replacement, and $0 \& M$ costs are just as important as manufacturing costs to the total battery system cost. Additional balanceof-plant and life-cycle cost studies are needed to develop a balanced set of cost characterizing information.

3. Complete cost analyses in more detail and more frequent $1 y$. More frequent cost analyses will minimize the problem of cost analyses becoming outdated by changes in technology.

Each of the recommendations cited above represents a part of an overall plan to enhance the state of battery cost analysis. The avaflability of quality cost data is seen as a first step in this plan. Consistent cost analyses completed for the entire battery system will lay the groundwork for the development of cost goals and R\&D plans, market assessments, and cost/performance tradeoffs. Figure 1 illustrates the relationship between activities designed to enhance the quality of battery cost data and the use of these data in related R\&D planning activities.

Specific battery cost analysis activities planned for FY 86 include the development of cost estimating guidelines, cost goals, a cost data base, and a model for evaluating cost/performance tradeoffs. Cost analysis guidelines will build from the $A$. D. Little/ EPRI manufacturing cost methodology to incorporate manufacturing inputs, installedsystem costs, and life-cycle costs as well. Cost goals will be based on the technical and economic capabilities of competitive energy systems. The data base and cost performance model will serve as tools for cost analys is evaluations in future years.

\section{PUBLICATIONS}

Brown, D. R. and J. A. Russell. A Review of Storage Battery System Cost Estimates. Pacific Northwest Laboratory, Richland, Washington. (Presently under review. Expected to be published in early 1986.)

Brown, D. R. and J. A. Russel1. 1985. "Status of Rattery Technology Cost Assessments." Proceedings of Seventh Battery and Electrochemical Contractors Conference, November 1985, Washington, D.C. 


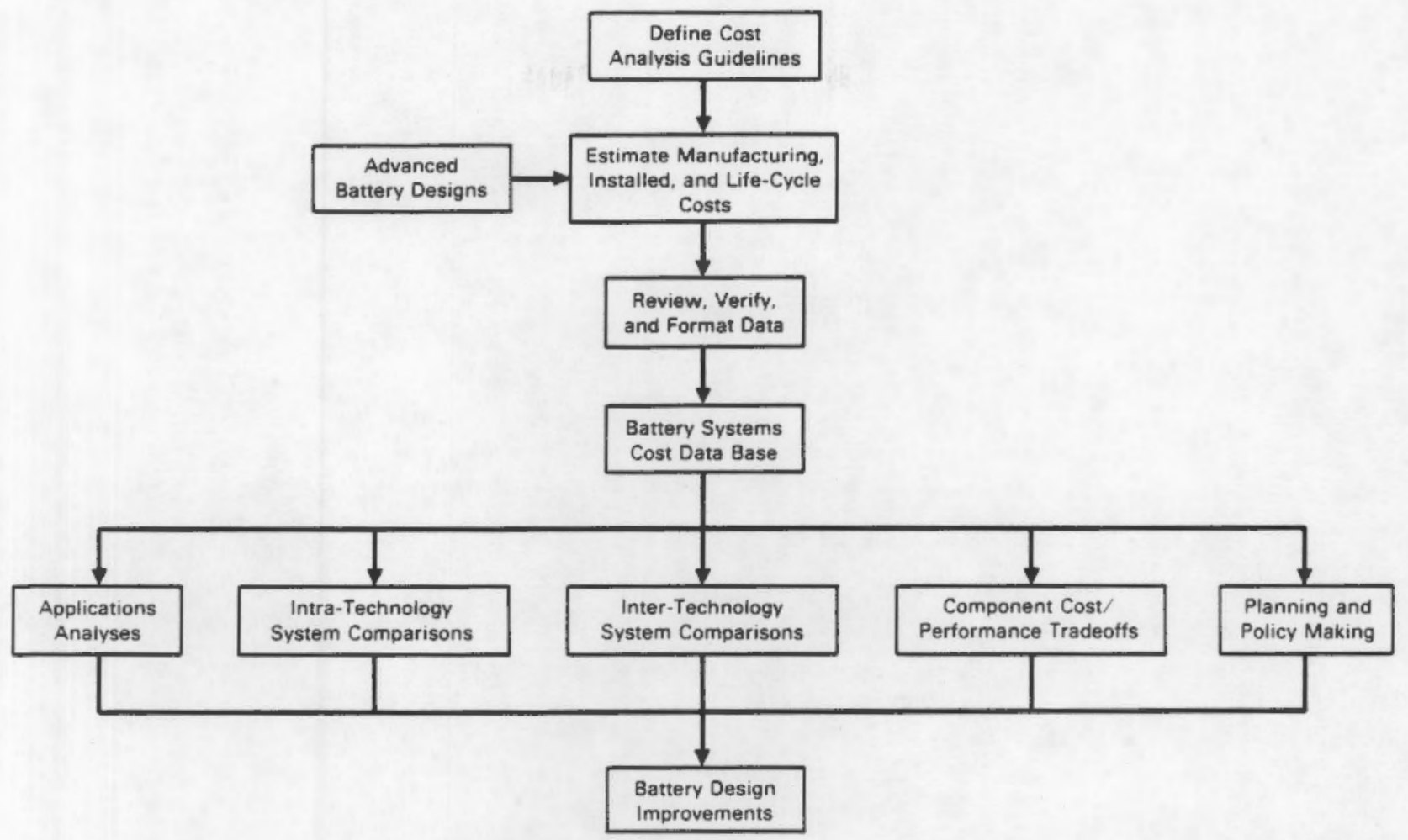

FIGURE 1. Battery Cost Analysis Work Flowsheet 



\section{R\&D PLANNING}

The goal of the R\&D Planning Task is to support the DOE-OESD in technology R\&D planning activities. Specific activities undertaken to achieve this goal include: 1) developing and updating key program planning documents, 2) coordinating program information management, and 3) implementing technology monitoring support. 



\section{INFORMATION MANAGEMENT}

Several activities related to program information management were completed in FY 1985. The primary product was a computerized system that provides several management services to the DOE Energy Storage Program. The system was developed for use on microcomputers and is supported by PNL staff. The key elements of the system's current version include: 1) a data base summarizing descriptive information on Energy Storage Program research, 2) an extensive mailing list for use by program participants, 3) a data base of program reference material for use by program participants in information dissemination, and 4) a planning system for monitoring the schedule and progress of key program activities.

The first element of this system, the Project Summaries Data Base, provides a format for summarizing key information for current research activities in the Energy Storage Program. The information, as depicted in Figure 1 , is updated on a

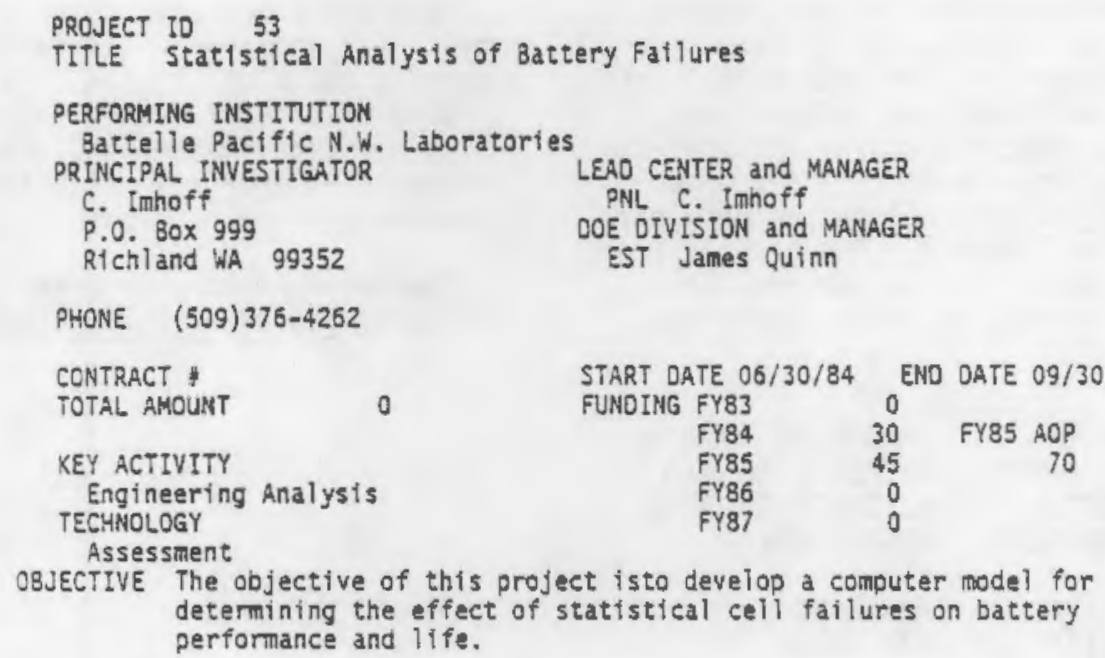

MILESTONES 06/30/85 Complete model valfdation.

$06 / 30 / 85$ Complete code development.

$09 / 30 / 85$ Complete the final report.

PROJECT DESCRIPTION:

ACcurate models of battery configurations can serve to evaluate the potential performance of a battery configuration before it is tested. Using this modeling technique, only configurations of superior multi-cell design shall be tested.

Development of analysis methods and tools to identify preferred multi-cell module test configurations and evaluation of their potential performance and risks before testingwill be undertaken. A battery systems engineering computer model using statistical estimation and risk concepts is being developed for the required calculations. The model uses existing data where possible to define failure probability distributions and the range of applicability. The analysis methods include reliability analysis routines for evaluation of the failure modes, probabilities, and performance effects so that attractive multi-cell configurations can be identified.

PUSL!CATION NUMBER:

TITLE: "Relfability Modeling System for Analysts of Advanced Battery Technologies"C.H. Imhoff IECEC 'B6 Conference, Mtami Fla.

FIGURE 1. Example Entry from the Project Summary Data Base 
quarterly basis per information from the lead centers and is available for use by $D O E$ staff. Common uses for the information include: 1) DOE review of research progress, 2) rapid summary of funding by key activity, laboratory, year, and state, 3) quick response to inquiries on goals and descriptions of specific research activity, 4) updating program bibliographies, and 5) rapid printing of a project summary publication printed for each contractors' conference.

The mailing list data base is designed to maintain information on key participants in the energy storage community. Currently, over 1500 names of scientists, government officials, and industry leaders from around the world who are involved and/or interested in energy storage are contained in the data base. The sample record displayed in Figure 2 represents the information requested from each individual in the data base. Note that in addition to address information, data describing specific topics of interest are maintained for each individual. The topics currently maintained in the data base are displayed in Figure 3 . The reports from the data base allow program personnel to quickly find information for an individual, identify groups with common interests, and print mailing labels for all or subsets of the data base.

The third element of the information system includes a data base for maintaining a directory of key program information materials. The current focus of this element is on briefing materials; in the near future, listings of the DOE library materials will be included. The final capability of the system is a planning system for recording and monitoring key program activities such as upcoming milestones, conferences, workshops, and program reviews.

\section{TECHNOLOGY MONITORING}

Technology monitoring activities over the past year included: 1) developing program summary documents to identify the current status of program technologies, and 2) planning and coordinating conferences and workshops to enhance communications both within and outside the program.

The major summary document published was entitled Status of the DOE Battery and

$\begin{array}{ll}\text { NAME } & \text { IMHOFF,MR. CARL H. } \\ \text { COMPANY } & \text { BATTELLE NW LABS } \\ \text { TITLE } & \text { RESEARCH ENGINEER } \\ \text { ADORESS } & \text { PO BOX } 999 \\ & \\ \text { CITY } & \text { RICHLAND } \\ \text { STATE, ZIP } & \text { WA } 99352 \\ \text { COUNTRY } & \\ \text { PHONE } & 5093764262 \\ \text { INTERESTS } & \text { Secondary Battery R\&D } \\ & \text { Lead-ACid } \\ & \text { Battery Testing } \\ & \text { End-Use Applications }\end{array}$

\author{
Sodium Sulfur \\ Metal Air \\ SYSTEM ECONOMICS \\ Utility Applications
}

FIGURE 2. Energy Storage Mailing List Report of Data Base Contents

PRI Primary Battery R\&D
SEC Secondary Battery R\&D
NAS Sodium Sulfur
ALK Alkaline
LTH Lithium
PBA Lead-Acid
MET Metal AIr
ZNH Zinc-Halogen
TES Battery Testing
OT1 Other Secondary Battery R\&D

BAS Basic Electrochemical Research
CAT Electrocatalysts
CON Elchem. Conversion (Fuel Cel1s)
COR Electrochemical Corrosion
MAT Materials \& Components Research
PHE Basic Electrochemical Phenomenona
VEH Fuel Cells for Vehicles
OT2 Other Basic Elchem. Research
END End-Use Applications
ELV Electric Vehicles
SOL Storage for Solar/Renew. Energy
UTL Utility Applications
OT3 Other End Use Interest


Electrochemical Technology Program V. This document summarized the current status of al1 technologies under development for DOE's Electrochemical Storage Program for the 18 months prior to June 1985. Two other summary documents were published in conjunction with the Seventh Electrochemical Contractors' Conference which was held late in Fy 1984. One provided brief informational summaries of each specific research project in the program. The second contained abstracts of papers that were presented at the conference.

Two meetings were planned and coordinated to aid technology monitoring. The first was the Seventh Annual Electrochemical Contractors' Conference that is described above; the second was an international workshop on battery testing. For this workshop, PNL staff provided assistance to DOE during the initial planning stages. The workshop was co-sponsored by DOE and the German government and was held in Heidelberg, Gemany in October 1985. PNL staff worked with representatives from Brown, Boveri, and Cie and
Argonne National Laboratory in structuring the workshop, contacting participants, and producing extended abstracts. PNL will publish the proceedings early in FY 1986.

\section{PUBLICATIONS}

Roberts, R. 1985. Status of the DOE Battery and Electrochemical Technology Program V. PNL-5448. Prepared by Roberts Consuttants, Inc., for Pacific Northwest Laboratory, Richland, Washington.

DOE. June 25-29, 1984. Extended Abstracts: Sixth DOE Electrical Contractors Review. CONF-840677. Prepared by Battelle Columbus Laboratories and Battelle, Pacific Northwest Laboratories, U. S. Department of Energy, Washington, D.C.

DOE. June 25-29, 1984 . Project Summaries: Sixth DOE Electrical Contractors Review. CONF-840677. Prepared by Battelle Columbus Laboratories and Battelle, Pacific Northwest Laboratories, U. S. Department of Energy, Washington, D.C. 


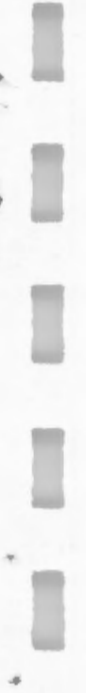

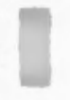

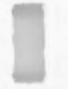

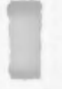

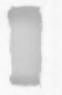

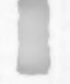

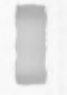

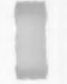

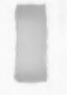

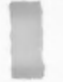

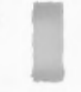

?

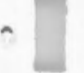

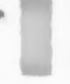




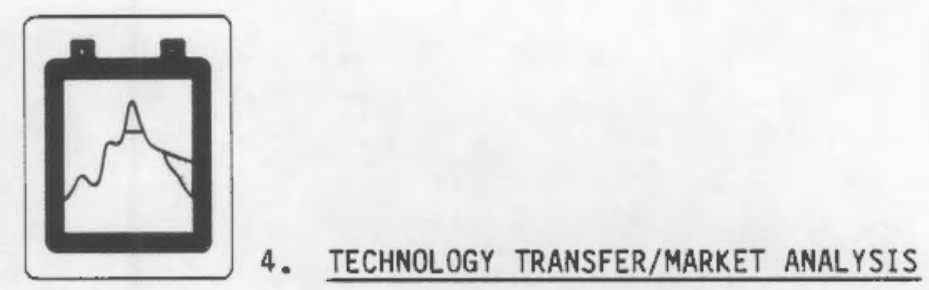

The DOE Energy Storage program has a long history of cooperating with industry and successfully transferring technology. Close cooperation with EPRI has resuited in the building and operation of the BEST facility and in joint development contracts for advanced batteries. Basic research success stories have resulted in improved technology in the primary battery, chloralkali, and lead-acid automobile batteries. Technology transfer is an ongoing part of the Energy Storage program and is integrated into the program planning and evaluation effort.

PNL has been asked to coordinate this technology transfer effort. Each research and development project has its own contacts and technology transfer mechanism. The role of PNL is not to interject itself into this process but to document each effort in the context of the entire program. Also, coordination of these various mechanisms into the R\&D planning process is another role.

The goal of this continuing effort is to provide a comprehensive plan and documentation of R\&D projects in the Energy Storage program. Additionally, the effort strives to coordinate the technology transfer function with the planning and evaluation functions of the program. 


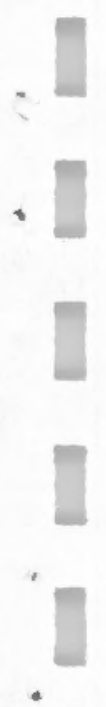

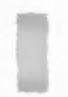

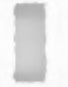

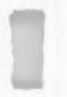

1

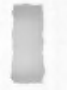

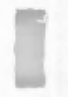

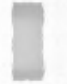

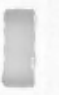

,

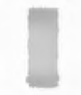

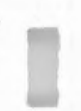

?

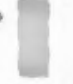




\section{BACKGROUND}

The DOE Battery Storage Program has been responsible for many improvements in the state of the art of battery technology. Improved grids have resulted in less costly and more reliable lead-acid batteries. Advanced battery technologies (e.g., zincchloride, zinc-bromine, and sodium-sulfur) offer the potential for improved performance at reduced cost. Moreover, battery improvements resulting from DOE research have found their way into consumer products such as hearing aids and other consumer appliances. The transfer of technology from federal government sponsored research is an important and continuing part of the DOE Energy Storage Program. Customer-side-of-the-meter (CSOM) battery storage is a proven concept that DOE and EPRI are aggressively pursuing as part of their technology transfer programs.

GOALS

The general goal of this task is to assist in the transfer of CSOM battery-storage technology to the marketplace. The approach taken to achieve this goal is to identify existing facilities and assess the technical and economic feasibility of installing leadacid battery storage at a customer's location for the purpose of saving electric power costs by reducing demand charges.

A specific goal is to identify at least one good public-sector site where CSOM battery-storage equipment can be installed. The primary targets are DOE facilities since many of them are very large electricity consumers. Also, DOE facilities are particularly sensitive to achieving reduction in energy costs and may be receptive to this DOE-developed technology. The second target group includes other federal government facilities such as Department of Defense (DOD) installations and facilities run by the General Services Administration. A third group would include state and local government facilities.

After one or more good candidates are identified, the goal is to provide technical and analytical assistance for the project. This will include acting as a liaison among EPRI, DOE, battery and electrical equipment manufacturers, and the electric utilities. Some financial assistance could be made availahle to support feasibility studies.

A related goal will be to publicize and generate interest in CSOM battery storage as part of an overall technology transfer program. Information and assistance will be made available so CSOM battery-storage analysts and decision makers can play an appropriate part in formulating energy plans. Once CSOM battery-storage installation is successfully operating, the effort will be focused to capitalize on this success.

\section{ACTIVITIES}

The technology transfer effort this year focused on promoting the use of battery storage to the utility industry and its customers. The earliest economic use of battery storage has been projected to be CSOM storage. Several institutional and regulatory issues have prevented the use of leadacid batteries by customers to reduce overall electricity costs. The purpose of the DOE effort is to overcome these barriers in an effort to promote battery storage.

Accomplishments under this task to date have primarily been in making contacts, gathering information, participating in workshops, and doing some preliminary analyses. The following discussions identify the major activities undertaken under this task and describe the accomplishments.

Identify and Contact DOE offices with Potential Interest or Information Regarding CSOM

An effort was made to identify and contact DOE offices that may have an interest in CSOM and that may be abie to provide some support or information. It was found that three different programs at DOE could potentially be of assistance: the In-house Energy Management Program, the Public Utilities Program, and the Federal Energy Management Program.

DOE's In-house Energy Management Program coordinates energy management activities within DOE. Among other things, it reviews funding requests and allocates funds for energy conservation and efficiency improvements at the various $D O E$ facilities.

The Public Utilities Program monitors electricity and gas utilities costs at DOE facilities and provides assistance to help reduce costs at those facilities. The Public Utilities Program is also concerned with utilities planning and ensuring adequate energy supplies for DOE facilities. The primary cost reduction effort under this program has emphasized obtaining low cost supplies from federal power marketing organizations (e.g., TVA and BPA) and intervening 
in rate cases before regulatory bodies. Apparently little emphas is has been placed on taking actions, such as load control, to reduce electricity demand or use.

The Federal Energy Management Program supports, encourages, and keeps account of energy conservation/efficiency efforts in the federal government. Support is provided primarily in the form of handbooks and workshops designed to help architects, energy managers, and others understand and comply with federal energy efficiency goals, procedures, and regulations. Much of this effort has been carried out by staff at the National Bureau of Standards (NBS). Staff from PNL attended a workshop conducted by NBS at which several handbooks and information for use in evaluating a software package were provided. The information obtained at that workshop was used primarily as input to the SYSPLAN model that has been developed to evaluate CSOM projects.

Identify and Contact Battery and Related Equipment Manufacturers to Assess Their Interest and Activities in CSOM

Battery and electrical equipment manufacturers were contacted to: 1) identify any good leads they might have regarding potential CSOM users, 2) obtain copies of any marketing materials, and 3) determine potential level of interest and sales efforts in the CSOM market.

Contacts with representatives of the leadacid battery manufacturers indicated that they are not actively marketing batteries for load leveling applications and are not likely to do so in the near future. Out of 23 contacts made with representatives of 16 different battery companies, only two companies indicated any interest in actively marketing the use of batteries for loadleveling applications. The other representatives indicated that their companies would discuss this application with interested customers and would sell them batteries but that they would not actively market the concept.

One of the two companies interested in this concept is continuing development of its zinc-chloride battery and intends to produce a commercial version for load-leveling applications. It does not appear to have any firm customers yet. The other company is currently testing its standard truck batteries in a load-leveling demonstration at one of its factories. Its interest stems as much from the potential application at various parent-company facilities as it does for serving the external load-leveling market.
Identify and Contact Organizations Involved in Previous or Ongoing CSOM Studies

PNL made contacts with representatives of six public organizations that had been previously identified by EPRI as having an interest in CSOM applications of batterystored energy. These organizations were the Long Island Railroad; the Washington, D.C. Metro; the U.S. Navy Base, San Diego; the U.S. Navy David Taylor Model Basin; and the U.S. Capitol complex.

The Long Island Railroad has received funding for an engineering/economic feasibility study of the CSOM battery-stored energy concept. The New York Power Authority is also involved. If the study results are positive, there is a good chance that a project would be undertaken. The study will not be completed and the results made publicly available until late 1985.

Contacts with the other organizations revealed some interest in the concept but little potential for projects involving CSOM battery-stored energy.

Identify and Contact DOE and Other Federal Facility Energy Managers

From a list of regional coordinators obtained from the DOE In-house Energy Management Program staff, an effort was made to contact the energy managers at the major $D O E$ facilities. The individuals that were contacted were asked about their familiarity with CSOM battery storage and an attempt was made to generate an interest in the concept. Little interest resulted from these contacts. The energy managers seemed to have difficulty visualizing how the technology could be applied to their situation. In part; this may be due to the fact that they were more accustomed to dealing with reductions in energy consumption rather than changing load profile to take advantage of electricity rate structures. Another possible reason for the reluctance to consider this concept is that the technology is not yet commercially available and, therefore, no firm performance or cost data can be provided.

\section{Develop SYSPLAN Model}

A model, called SYSPLAN, was developed to use in evaluating the economic feasibility of CSOM battery storage at specific sites. SYSPLAN, which operates on an IBM-PC, is designed to perform a preliminary feasibility analysis. It is not a substitute for a detailed engineering costing study, but is useful as a tool for screening candidates. 
Organize and Carry Out Other Related Activities

Assistance was provided to DOE, EPRI, and Public Service Electric and Gas Company in planning and organizing the Workshop on Batteries for Utility Applications, Load Management, and Supply-Side Management held in April 1985. A presentation on DOE/EPRI activities was made and the SYSPLAN model was demonstrated.

Future activity in this task will be based on identifying opportunities in the public sector where the CSOM battery storage loadleveling concept can be applied. After opportunities are identified, locations will be identified and preliminary evaluations and feasibility studies will be conducted.
A working relationship among the principal beneficiaries of applying the concept (e.g., battery manufacturers, utilities, financiers, customers) will also be facilitated as plans proceed toward achieving a commercial installation.

\section{PUBLICATIONS}

Hurwitch, J. W. 1985. "EPRI/DOE Role in Customer Side of the Meter Battery Storage." In Proceedings for Workshop on Batteries for Utility Applications, Load Management, and Supply-Side Management. Sponsored by the U.S. Department of Energy, the Electric Power Research Institute, and Public Service Electric and Gas Company, Apríl 16-18, 1985, Newark, New Jersey. 
<smiles>[124IH]</smiles><smiles></smiles><smiles>[AlH]</smiles><smiles>C1CCCCC1</smiles><smiles>[CH]1CCC1</smiles><smiles>C1CCC1</smiles><smiles>[AlH2]</smiles><smiles>[AlH2]</smiles><smiles>B</smiles><smiles>[Li]</smiles> 
No. of

Copies

OFFSITE

$40 \mathrm{Mr} . J$. E. Quinn

U.S. Department of Energy

Forrestal Building, Rm 6A049

1000 Independence Avenue, SW

Washington, DC 20585

Dr. A. R. Landgrebe

U.S. Department of Energy

Electrochemical Energy Storage

CE-141, MS 5 E-036

Forrestal Building

1000 Independence Avenue, SW

Washington, DC 20585

30 DOE Technical Information Center

Dr. J. Birk

Electric Power Research Institute

3412 Hillview Avenue

P.0. Box 10412

Palo Alto, CA 94303

Mr. P. Brown

CE-132

U.S. Department of Energy

Forrestal Building

1000 Independence Avenue, SW

Washington, DC 20585

Dr. R. P. Clark

Sandia National laboratories

P.0. Box 5800

Albuquerque, NM 87185

Mr. M. Chiogigi

U.S. Department of Energy

Forrestal Building

1000 Independence Avenue, SW

Washingt on, DC 20585

Mr. K. Grothaus

Sandia National Laboratory

P.0. Box 5800

Albuquerque, NM 87185

Mr. F. R. Kalhammer

Electric Power Research

Institute

3412 Hillview Avenue

P.0. Box 10412

Palo Alto, CA 94303
No. of

Copies

Mr. K. W. Klein

U.S. Department of Energy

Forrestal Building

1000 Independence Avenue, SW

Washington, DC 20585

Dr. K. Kinoshita

Lawrence Berkeley Laboratory

Energy and Environment Division

Building 90, 3rd Floor Rm 3026

Berkeley, CA 94720

Mr. R. Kirk

U.S. Department of Energy

Office of Transportation Systems

1000 Independence Avenue, SW

Washington, DC 20585

Dr. F. McLarnon

Lawrence Berkeley Laboratory

Building 90, Room 3026

Berkeley, CA 94720

Dr. N. J. Magnani

Sandia National Laboratory

P.0. Box 5800

Albuquerque, NM 87185

\section{ONSITE}

2 DOE - Richland Operations

0. Segna

D. Jones

120 Pacific Northwest Laboratory

W. B. Ashton

W. W. Ballard

D. R. Brown

C. A. Counts

J. R. Divine

R. M. Fleischman

B. J. Harrer

C. J. Hostick

J. W. Hurwitch

C. H. Imhoff $(100)$

B. L. Mohler

J. A. Russell

R. K. Sen

T. A. Willians

Publishing Coordination MH (2)

Technical Information (5) 


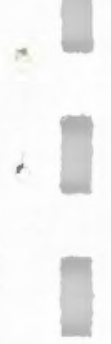

I 